\title{
AIRUSE-LIFE+: a harmonized PM speciation and source apportionment in five southern European cities
}

\author{
Fulvio Amato ${ }^{1}$, Andrés Alastuey ${ }^{1}$, Angeliki Karanasiou ${ }^{1}$, Franco Lucarelli ${ }^{2}$, Silvia Nava $^{2}$, Giulia Calzolai $^{2}$, \\ Mirko Severi $^{3}$, Silvia Becagli ${ }^{3}$, Vorne L. Gianelle ${ }^{4}$, Cristina Colombi $^{4}$, Celia Alves ${ }^{5}$, Danilo Custódio ${ }^{5}$, Teresa Nunes ${ }^{5}$, \\ Mario Cerqueira ${ }^{5}$, Casimiro Pio $^{5}$, Konstantinos Eleftheriadis ${ }^{6}$, Evangelia Diapouli ${ }^{6}$, Cristina Reche ${ }^{1}$, María \\ Cruz Minguillón $^{1}$, Manousos-Ioannis Manousakas ${ }^{6}$, ${\text { Thomas } \text { Maggos }^{6}, \text { Stergios Vratolis }^{6} \text {, Roy M. Harrison }}^{7, a}$, and \\ Xavier Querol $^{1}$ \\ ${ }^{1}$ Institute of Environmental Assessment and Water Research (IDAEA-CSIC), 08034 Barcelona, Spain \\ ${ }^{2}$ Department of Physics and Astronomy, Università di Firenze and INFN-Firenze, 50019 Sesto Fiorentino, Italy \\ ${ }^{3}$ Department of Chemistry, Università di Firenze, 50019 Sesto Fiorentino, Italy \\ ${ }^{4}$ Environmental Monitoring Sector, Arpa Lombardia, Via Rosellini 17, 20124 Milan, Italy \\ ${ }^{5}$ Centre for Environmental \& Marine Studies, Department of Environment, University of Aveiro, 3810-193 Aveiro, Portugal \\ ${ }^{6}$ Institute of Nuclear and Radiological Sciences \& Technology, Energy \& Safety, N.C.S.R. Demokritos, \\ 15341 Ag. Paraskevi, Attiki, Greece \\ ${ }^{7}$ School of Geography, Earth \& Environmental Sci., University of Birmingham, Edgbaston, Birmingham, B15 2TT, UK \\ a also at: Department of Environmental Sciences/Center of Excellence in Environmental Studies, \\ King Abdulaziz University, P.O. Box 80203, 21589 Jeddah, Saudi Arabia
}

Correspondence to: Fulvio Amato (fulvio.amato@idaea.csic.es)

Received: 11 June 2015 - Published in Atmos. Chem. Phys. Discuss.: 4 September 2015

Revised: 2 February 2016 - Accepted: 22 February 2016 - Published: 14 March 2016

\begin{abstract}
The AIRUSE-LIFE+ project aims at characterizing similarities and heterogeneities in particulate matter (PM) sources and contributions in urban areas from southern Europe. Once the main PMx sources are identified, AIRUSE aims at developing and testing the efficiency of specific and non-specific measures to improve urban air quality. This article reports the results of the source apportionment of $\mathrm{PM}_{10}$ and $\mathrm{PM}_{2.5}$ conducted at three urban background sites (Barcelona, Florence and Milan, BCN-UB, FIUB and MLN-UB), one suburban background site (Athens, ATH-SUB) and one traffic site (Porto, POR-TR). After collecting $1047 \mathrm{PM}_{10}$ and $1116 \mathrm{PM}_{2.5} 24 \mathrm{~h}$ samples during 12 months (from January 2013 on) simultaneously at the five cities, these were analysed for the contents of OC, EC, anions, cations, major and trace elements and levoglucosan. The USEPA PMF5 receptor model was applied to these data sets in a harmonized way for each city.

The sum of vehicle exhaust (VEX) and non-exhaust (NEX) contributes between 3.9 and $10.8 \mu \mathrm{g} \mathrm{m}^{-3}(16-32 \%)$ to $\mathrm{PM}_{10}$ and 2.3 and $9.4 \mu \mathrm{g} \mathrm{m}^{-3}(15-36 \%)$ to $\mathrm{PM}_{2.5}$, although
\end{abstract}

a fraction of secondary nitrate is also traffic-related but could not be estimated. Important contributions arise from secondary particles (nitrate, sulfate and organics) in $\mathrm{PM}_{2.5}$ (37$82 \%$ ) but also in $\mathrm{PM}_{10}(40-71 \%)$, mostly at background sites, revealing the importance of abating gaseous precursors in designing air quality plans.

Biomass burning (BB) contributions vary widely, from $14-24 \%$ of $\mathrm{PM}_{10}$ in POR-TR, MLN-UB and FI-UB, $7 \%$ in ATH-SUB, to $<2 \%$ in BCN-UB. In $\mathrm{PM}_{2.5}, \mathrm{BB}$ is the second most important source in MLN-UB (21\%) and in POR-TR (18\%), the third one in FI-UB (21\%) and ATHSUB $(11 \%)$, but is again negligible $(<2 \%)$ in BCN-UB. This large variability among cities is mostly due to the degree of penetration of biomass for residential heating. In Barcelona natural gas is very well supplied across the city and is used as fuel in $96 \%$ of homes, while in other cities, PM levels increase on an annual basis by $1-9 \mu \mathrm{g} \mathrm{m}^{-3}$ due to biomass burning influence. Other significant sources are the following. 
- Local dust, 7-12\% of $\mathrm{PM}_{10}$ at SUB and UB sites and $19 \%$ at the TR site, revealing a contribution from road dust resuspension. In $\mathrm{PM}_{2.5}$ percentages decrease to 2$7 \%$ at SUB-UB sites and $15 \%$ at the TR site.

- Industry, mainly metallurgy, contributing $4-11 \%$ of $\mathrm{PM}_{10}\left(5-12 \%\right.$ in $\mathrm{PM}_{2.5}$ ), but only at BCN-UB, PORTR and MLN-UB. No clear impact of industrial emissions was found in FI-UB and ATH-SUB.

- Natural contributions from sea salt (13\% of $\mathrm{PM}_{10}$ in POR-TR, but only $2-7 \%$ in the other cities) and Saharan dust (14\% in ATH-SUB, but less than $4 \%$ in the other cities).

During high pollution days, the largest sources (i.e. excluding secondary aerosol factors) of $\mathrm{PM}_{10}$ and $\mathrm{PM}_{2.5}$ are VEX + NEX in BCN-UB (27-22\%) and POR-TR (31$33 \%)$, BB in FI-UB (30-33\%) and MLN-UB (35-26\%) and Saharan dust in ATH-SUB (52-45\%). During those days, there are also quite important industrial contributions in BCN-UB (17-18\%) and local dust in POR-TR (28-20\%).

\section{Introduction}

Atmospheric particulate matter (PM) concentrations can vary widely across Europe due to different climatic conditions and local features such as anthropogenic source types, emission rates and dispersion patterns. Urban $\mathrm{PM}_{10}$ concentrations show significant variability across Europe as reported by routine monitoring networks (EEA, 2015) and research studies (Querol et al., 2004; Putaud et al., 2010; Lianou et al., 2011; Kukkonen et al., 2005; Karanasiou et al., 2014). For $\mathrm{PM}_{2.5}$ the spatial variability across southern Europe is less known because in most air quality zones it is not as widely measured as $\mathrm{PM}_{10}$. As a consequence, there is limited information on the geographical variability of the coarse fraction $\left(\mathrm{PM}_{10}-\mathrm{PM}_{2.5}\right)$, which is often linked to local sources and whose evidence of health concern is increasing (Brunekreef and Forsberg, 2005).

Comparability of data is also hampered by the fact that most research studies analysed PM data from different periods or with different sampling calendars. An example of this is given by the multi-city studies aimed at investigating the short- and long-term health effects of exposure to $\mathrm{PM}_{x}$ mass concentrations, $\mathrm{NO}_{x}$ and $\mathrm{SO}_{2}$ (Eeftens et al., 2012; Medina et al., 2004; Meng et al., 2013; Romieu et al. 2012).

Moreover, the comparison of bulk PM concentrations only, without the necessary chemical characterization of collected samples and source apportionment analysis, does not allow for an in-depth investigation of sources, limiting the scope for air quality management purposes.

Recent studies have reported the $\mathrm{PM}_{10}$ and $\mathrm{PM}_{2.5}$ concentrations across Europe, but no information on PM composition and sources was provided (Karanasiou et al., 2014;
Lianou et al., 2011). In another study, Querol et al. (2004) compared the $\mathrm{PM}_{10}$ and $\mathrm{PM}_{2.5}$ levels and chemistry of seven selected EU regions, but data sets were not simultaneous from 1998 to 2002. The ESCAPE project (Eeftens et al., 2012) investigated the health effects of long-term exposure to ambient air pollution across Europe. $\mathrm{PM}_{2.5}, \mathrm{PM}_{10}$ and particle composition were compared at 20 sites across 2008 2011, but measurements were done three times for 14 days in different seasons without covering the full year period.

The AIRUSE LIFE+ project generated the first harmonized data set of southern European cities for $\mathrm{PM}_{10}$ and $\mathrm{PM}_{2.5}$ levels and composition, following the same sampling protocol and 12-month calendar in Barcelona (Spain), Porto (Portugal), Florence and Milan (Italy) and Athens (Greece). The goal is to characterize the similarities and heterogeneities in PM sources and contributions across the Mediterranean region. This article describes the source apportionment results for $\mathrm{PM}_{10}$ and $\mathrm{PM}_{2.5}$, highlighting common features and dissimilarities across southern Europe. Once the main sources of $\mathrm{PM}_{10}$ and $\mathrm{PM}_{2.5}$ are identified, the strategic goal of the AIRUSE project is to test and develop specific measures to improve air quality in southern Europe, targeted to meet air quality standards and to approach as closely as possible the WHO guidelines.

\section{Methods}

\subsection{PM sampling}

PM sampling was carried out from January 2013 during 12 months simultaneously at five sites in Barcelona, Porto, Florence, Milan and Athens. $\mathrm{PM}_{10}$ and $\mathrm{PM}_{2.5} 24 \mathrm{~h}$ samples were collected simultaneously every third day. Furthermore, in order to evaluate the chemical fingerprint of Saharan dust, additional $\mathrm{PM}_{10}$ and $\mathrm{PM}_{2.5}$ sampling was performed at each city under selected Saharan dust intrusions after forecasting the occurrence of this phenomenon. The forecast was based on the interpretation of (i) air mass back trajectories calculated with the HYSPLIT4 model from NOAA (Draxler and Rolph, 2003) and (ii) predictions of dust concentrations by the SKIRON model, University of Athens (http://forecast.uoa.gr.html) and Barcelona Supercomputing Center (NMMB/BSC-Dust forecasts) prediction models.

The details of each monitoring site and instrumentation used are described below.

- BCN-UB: Barcelona urban background (Spain). This is an urban background (UB) site located within the university campus (south-western part of the city) and is part of the local air quality network. The nearest trafficked road (Diagonal Avenue, 90000 vehicles/day) is located $200 \mathrm{~m}$ away. $\mathrm{PM}_{10}$ and $\mathrm{PM}_{2.5}$ were collected by means of sequential DIGITEL DH1080 high-volume samplers $\left(30 \mathrm{~m}^{3} \mathrm{~h}^{-1}\right)$ on $150 \mathrm{~mm}$ diameter quartz fi- 
bre filters at the Palau Reial station $\left(41^{\circ} 23^{\prime} 14^{\prime \prime} \mathrm{N}\right.$, $\left.2^{\circ} 6^{\prime} 56^{\prime \prime} \mathrm{E}\right)$.

- POR-TR: Porto traffic (Portugal). The urban traffic (TR) station is located in Praça Francisco Sá Carneiro $\left(41^{\circ} 09^{\prime} 46.10^{\prime \prime} \mathrm{N}, 8^{\circ} 35^{\prime} 26.95^{\prime \prime} \mathrm{W}\right)$ and is part of the national air quality network, QualAr. It is located on the eastern side of Porto, next to Fernão de Magalhães Avenue and $600 \mathrm{~m}$ from the inner circular motorway. Two low-volume samplers (TECORA) operating at $2.3 \mathrm{~m}^{3} \mathrm{~h}^{-1}$ collected $\mathrm{PM}_{10}$ and $\mathrm{PM}_{2.5}$ onto $47 \mathrm{~mm}$ diameter Teflon filters. A high-volume sampler operating at a flow of $1113 \mathrm{~L} \mathrm{~min}^{-1}$ with impaction plates from Sierra-Andersen, which enabled the simultaneous collection of $\mathrm{PM}_{2.5}$ and $\mathrm{PM}_{2.5-10}$ onto quartz fibre filters, was used in parallel.

- FI-UB: Florence urban background (Italy). The urban site of Bassi is an air quality UB monitoring station $\left(43^{\circ} 47^{\prime} 8.33^{\prime \prime} \mathrm{N}, 11^{\circ} 17^{\prime} 13.19^{\prime \prime} \mathrm{E}\right)$ of the Environmental Protection Agency of Tuscany. $\mathrm{PM}_{10}$ and $\mathrm{PM}_{2.5}$ samples were collected by means of two low-volume $\left(2.3 \mathrm{~m}^{3} \mathrm{~h}^{-1}\right)$ CEN equivalent sequential samplers (HYDRA Dual Sampler); each sampler is equipped with two inlets so that aerosol can be simultaneously collected on Teflon membrane and quartz microfibre filters $(47 \mathrm{~mm}$ diameter, Pall R2PJ047 and Aquaria QF1, respectively).

- ATH-SUB: Athens suburban background (Greece). This station is part of the Global Atmosphere Watch network (GAW-DEM) and is located on the NCSR Demokritos campus $\left(37^{\circ} 99^{\prime} 50^{\prime \prime} \mathrm{N}, 23^{\circ} 81^{\prime} 60^{\prime \prime} \mathrm{E}\right)$, at the north-eastern corner of the Greater Athens Metropoli$\tan$ Area and at an altitude of $270 \mathrm{~m}$ a.s.l. The suburban site is away from direct emission sources in a vegetated area (pine). $\mathrm{PM}_{10}$ and $\mathrm{PM}_{2.5}$ samples were collected on Teflon filters by means of low-volume $\left(2.3 \mathrm{~m}^{3} \mathrm{~h}^{-1}\right)$ samplers (Sequential 47/50-CD with Peltier cooler, Sven Leckel GmbH, a Tecora Echo PM sampler and a Demokritos EN12341 sampler). $\mathrm{PM}_{10}$ and $\mathrm{PM}_{2.5}$ samples were also collected on quartz microfibre filters by means of high-volume samplers (Sequential HighVolume Sampler CAV-A/MSb, MCV, SA).

- MLN-UB: Milan urban background (Italy). The Milano Pascal urban background station is part of the ARPA Lombardia Air Quality Network, and it is one of the Italian supersites for Italian decree 155/2010 (Italian transposition of 2008/50/CE). It is located on the eastern side of Milan, the University area called Città Studi $\left(45^{\circ} 28^{\prime} 44^{\prime \prime} \mathrm{N}, 9^{\circ} 14^{\prime} 07^{\prime \prime} \mathrm{E}\right)$, in a playground about $130 \mathrm{~m}$ from the road traffic. $\mathrm{PM}_{10}$ and $\mathrm{PM}_{2.5}$ were collected on Teflon (Pall), mixed cellulose ester (MCE, Advantec) and quartz microfibre (Pall) filters ( $47 \mathrm{~mm}$ diameter), with five low-volume US-EPA reference method samplers (TECORA).

\subsection{Sample treatment and analysis}

Before sampling, quartz or PTFE microfibre filters were dried for $5 \mathrm{~h}$ and conditioned for $48 \mathrm{~h}$ at $20^{\circ} \mathrm{C}$ and $50 \%$ of relative humidity. Weights of blank filters were measured three times every $24 \mathrm{~h}$ by means of a microbalance ( 1 or $10 \mu \mathrm{g}$ sensitivity). After weighing, $\varnothing 47 \mathrm{~mm}$ filters were kept in Petri holders, while $\varnothing 15 \mathrm{~cm}$ and large rectangular filters were kept in aluminium foils. After sampling, filters were brought back to the laboratory to be weighed two more times every $24 \mathrm{~h}$ of conditioning at the same temperature and relative humidity as the first weighing.

Once the weights of samples were determined, filters were destined for several analytical determinations. These procedures are briefly listed below, according to the different species analysed.

- Major and trace elements were determined

- in Teflon filters by different techniques: PIXE (particle-induced X-ray emission) without any pretreatment (Lucarelli et al., 2014); after acid digestion $\left(5 \mathrm{~mL} \mathrm{HF}, 2.5 \mathrm{~mL} \mathrm{HNO}_{3}, 2.5 \mathrm{~mL} \mathrm{HClO}_{4}\right)$ of $1 / 2$ of each filter, consecutively by ICP-MS (inductively coupled plasma mass spectrometry) and ICP-AES (inductively coupled plasma atomic emission spectroscopy) (Querol et al., 2001) to assure comparability between the two techniques (only for Porto samples, Fig. S1 in the Supplement); by ICP-AES after digestion with $\mathrm{HNO}_{3}$ $\mathrm{H}_{2} \mathrm{O}_{2}$ in a microwave oven according to EU method EN14902:2005 (Traversi et al., 2014), only for Florence samples (Fig. S1); by XRF (X-ray fluorescence) with a polarized primary $\mathrm{X}$-ray beam and several secondary targets, after an intercomparison with PIXE (Fig. S2), only for Milan samples (Table S1 in the Supplement);

- in quartz filters by ICP-MS and ICP-AES after acid digestion ( $\left.5 \mathrm{~mL} \mathrm{HF}, 2.5 \mathrm{~mL} \mathrm{HNO}_{3}, 2.5 \mathrm{~mL} \mathrm{HClO}_{4}\right)$ of 1/4 of each filter (Querol et al., 2001) (Table S1); and

- in Teflon and MCE filters by XRF (X-ray fluorescence), only for Milan samples.

- Water-soluble ions by IC (ion chromatography), after extraction in $20 \mathrm{~mL}$ of MilliQ water (with an ultrasonic bath for $30 \mathrm{~min}$ ) of $1 / 2$ or $1 / 4$ of filter

- On quartz filters, organic carbon (OC) and elemental carbon (EC) by thermal-optical analysis with the EUSAAR2 temperature program by means of Sunset analysers. Filters from POR-TR were analysed in a thermaloptical transmission system described in detail elsewhere, following a similar protocol of EUSAAR2 (Pio et al., 1998, 2011). 
- On the $\mathrm{PM}_{10}$ quartz microfibre filters, carbonate carbon (CC), by means of the procedure described by Pio et al. (1994): briefly, the carbonate measurement set-up comprises four components: a mass flow meter, a reaction cell, an infrared $\mathrm{CO}_{2}$ analyser, and a computer terminal for data acquisition. A portion of each filter $(9 \mathrm{~mm}$ punches) is acidified with orthophosphoric acid (20\%) in a $\mathrm{CO}_{2}$ free gas stream to convert the carbonate carbon to $\mathrm{CO}_{2}$, which is then detected by an infrared analyser.

- On the $\mathrm{PM}_{2.5}$ quartz filters, levoglucosan was determined by means of IC after extraction in $10 \mathrm{~mL}$ of MilliQ water (with an ultrasonic bath for $30 \mathrm{~min}$ ) on a $1.5 \mathrm{~cm}^{2}$ punch of filter (Table S1).

The ICP-MS, PIXE, GC-MS, CC and XRF analyses were carried out by one laboratory for each technique, while IC and ECOC analyses were separated among the five laboratories.

\subsection{Source apportionment}

Source apportionment studies of atmospheric particulate matter are often performed by means of receptor models that are based on the mass conservation principle:

$x_{i j}=\sum_{k=1}^{p} g_{i k} f_{j k}+e_{i j} i=1,2, \ldots, m j=1,2 \ldots n$,

where $x_{i j}$ is the concentration of the species $j$ in the $i$ th sample, $g_{i k}$ is the contribution of the $k$ th source in the $i$ th sample, $f_{j k}$ is the concentration of the species $j$ in source $k$, and $e_{i j}$ is the error of each individual datum. Equation (1) can also be expressed in matrix form as $\mathbf{X}=\mathbf{G F}^{T}$. If $f_{j k}$ is known for all the sources, then the chemical mass balance (CMB) can be applied (Watson et al., 1984), as for this model the experimental profiles of all major sources are needed. When both $g_{i k}$ and $f_{j k}$ are unknown, factor analysis (FA) techniques such as principal component analysis (PCA) (Thurston and Spengler, 1985; Henry and Hidy, 1979 ) and positive matrix factorization (PMF) (Paatero and Tapper, 1994) are used for solving Eq. (1). PMF can be solved with the Multilinear Engine (ME-2) developed by Paatero (1999) and implemented in version 5 of the US EPA PMF (http://www.epa.gov/heasd/research/pmf.html).

In this study, the US EPA PMF v5 was applied to the five data sets obtained at BCN-UB, FI-UB, ATH-SUB, MLN$\mathrm{UB}$ and POR-TR. Since PMF is a weighted least-squares method, individual estimates of the uncertainty in each data value are needed. The uncertainty estimates were based on the approaches by Polissar et al. (1998), Amato et al. (2009) and Escrig Vidal et al. (2009). Species which retain a significant signal were separated from the ones dominated by noise, following the signal-to-noise $(S / N)$ criterion defined by Paatero and Hopke (2003). Species with $S / N<0.2$ are generally defined as bad variables and removed from the analysis, and species with $0.2<S / N<2$ are generally defined as weak variables and down-weighted (increasing uncertainty by a factor of 3). Nevertheless, since $S / N$ is very sensitive to sporadic values much higher than the level of noise, the percentage of data above the detection limit was used as a complementary criterion.

In those cases where the PMF model was not able to resolve a Saharan dust source, the Saharan dust contribution was estimated according to the methodology proposed by SEC (2011).

\section{Results and discussion}

\section{1 $\quad \mathrm{PM}_{10}$ and $\mathrm{PM}_{2.5}$ levels}

As shown in Table 1, the observed mean PM levels during the study period were as follows.

- $\mathrm{PM}_{10}$ in the urban background (UB) reached 19$23 \mu \mathrm{g} \mathrm{m}^{-3}$ in FI and BCN, and $38 \mu \mathrm{g} \mathrm{m}^{-3}$ in MLN. At the suburban background (SUB) site in ATH, levels reached $20 \mu \mathrm{g} \mathrm{m}^{-3}$, whereas at the traffic (TR) site of POR, concentrations reached $34 \mu \mathrm{g} \mathrm{m}^{-3}$.

- For $\mathrm{PM}_{2.5}$, levels reached $13-15 \mu \mathrm{g} \mathrm{m}^{-3}$ at the UB sites of FI and BCN, $30 \mu \mathrm{g} \mathrm{m}^{-3}$ in MLN, $11 \mu \mathrm{g} \mathrm{m}^{-3}$ at the SUB site in Athens, and $27 \mu \mathrm{g} \mathrm{m}^{-3}$ in POR-TR.

All sites met EU legal requirements (Council Directive 2008/50/EC) for the annual limit value of $\mathrm{PM}_{10}$ $\left(40 \mu \mathrm{g} \mathrm{m}^{-3}\right)$. However, the legal requirement of not exceeding $50 \mu \mathrm{g} \mathrm{m}^{-3}$ for the 90.4 th percentile of the annual data (daily limit value) was exceeded at MLN-UB $\left(72 \mu \mathrm{g} \mathrm{m}^{-3}\right)$ and POR-TR $\left(53 \mu \mathrm{g} \mathrm{m}^{-3}\right)$. The annual EU target value of $\mathrm{PM}_{2.5}\left(25 \mu \mathrm{g} \mathrm{m}^{-3}, 2008 / 50 / \mathrm{EC}\right)$ was exceeded at POR-TR $\left(27 \mu \mathrm{g} \mathrm{m}^{-3}\right)$ and MLN-UB $\left(29 \mu \mathrm{g} \mathrm{m}^{-3}\right)$. For the UB sites mean $\mathrm{PM}_{10}$ levels are similar, with the exception of MLN with relatively higher levels, due to intense local and regional PM source contributions and to the specific meteorology of the Po Valley, with frequent and intensive atmospheric thermal inversions that induce regional accumulation of pollutants.

For $\mathrm{PM}_{2.5}$, similar and relatively lower values (as compared with $\mathrm{PM}_{10}$ ) were recorded at UB and SUB sites (11$\left.15 \mu \mathrm{g} \mathrm{m}^{-3}\right)$, with the exception of MLN $\left(30 \mu \mathrm{g} \mathrm{m}^{-3}\right)$. In the case of the TR site, the mean level reached $27 \mu \mathrm{g} \mathrm{m}^{-3}$. UB and SUB $\mathrm{PM}_{2.5} / \mathrm{PM}_{10}$ ratios were close to 0.7 in the case of FI and BCN, 0.5 for ATH and 0.8 for MLN. At the PORTR site it increased to 0.8. Although at the TR site levels of resuspension of road dust (mainly in the coarse size) are expected to be higher than at UB sites, the proximity to the exhaust emissions (dominated by fine PM) results in a higher $\mathrm{PM}_{2.5} / \mathrm{PM}_{10}$ ratio.

When considering the stricter WHO guidelines, all cities exceeded both the $\mathrm{PM}_{10}$ and $\mathrm{PM}_{2.5}$ annual mean thresholds, with the exception of $\mathrm{PM}_{10}$ in FI-UB. It is worth noting 
Table 1. Mean PM and component concentrations for the study period at the five AIRUSE cities. NA: not available.

\begin{tabular}{|c|c|c|c|c|c|c|c|c|c|c|}
\hline \multirow[b]{2}{*}{$n g m^{-3}$} & \multicolumn{5}{|c|}{$\mathrm{PM}_{10}$} & \multicolumn{5}{|c|}{$\mathrm{PM}_{2.5}$} \\
\hline & BCN-UB & POR-TR & FI-UB & MLN-UB & ATH-SUB & BCN-UB & POR-TR & FI-UB & MLN-UB & ATH-SUB \\
\hline PM & 22526 & 34520 & 18896 & 38074 & 19782 & 15001 & 26680 & 13213 & 30129 & 11003 \\
\hline p90.4 & 33578 & 52869 & 31094 & 65644 & 30946 & & & & & \\
\hline $\mathrm{OM}$ & 4959 & 7625 & 9634 & 15354 & 5556 & 4400 & 7783 & 8162 & 11741 & 4631 \\
\hline $\mathrm{TC}$ & 3863 & 10969 & 6440 & 10357 & 3684 & 3444 & 11288 & 5468 & 8307 & 3048 \\
\hline $\mathrm{EC}$ & 1108 & 4814 & 1088 & 1827 & 416 & 1000 & 5006 & 934 & 1784 & 324 \\
\hline $\mathrm{OC}$ & 2755 & 6155 & 5352 & 8530 & 3268 & 2444 & 6282 & 4534 & 6523 & 2724 \\
\hline $\mathrm{CO}_{3}^{2-}$ & 151 & 35 & 144 & 29 & 34 & NA & NA & NA & NA & NA \\
\hline $\mathrm{SO}_{4}^{2-}$ & 1985 & 2470 & 1737 & 3001 & 3651 & 1685 & 2000 & 1542 & 1934 & 2888 \\
\hline $\mathrm{NO}_{3}^{-}$ & 1990 & 1954 & 1184 & 6009 & 1164 & 922 & 1198 & 639 & 5675 & 173 \\
\hline $\mathrm{NH}_{4}^{+}$ & 604 & 703 & 496 & 3327 & 1013 & 709 & 658 & 548 & 2201 & 943 \\
\hline Levoglucosan & NA & NA & NA & NA & NA & 20 & 387 & 255 & 274 & 37 \\
\hline $\mathrm{K}$ & 176 & 429 & 250 & 373 & 251 & 87 & 343 & 172 & 303 & 115 \\
\hline S & 751 & 890 & 780 & 1089 & 1255 & 581 & 782 & 698 & 1071 & 911 \\
\hline $\mathrm{Cl}$ & 599 & 2284 & 254 & 341 & 617 & 178 & 690 & 22 & 272 & 41 \\
\hline $\mathrm{Na}$ & 697 & 1488 & 375 & 190 & 670 & 163 & 440 & 59 & 178 & 112 \\
\hline $\mathrm{Mg}$ & 155 & 283 & 116 & 113 & 210 & 40 & 82 & 17 & 21 & 35 \\
\hline $\mathrm{Al}$ & 225 & 444 & 194 & 282 & 400 & 66 & 226 & 39 & 149 & 90 \\
\hline $\mathrm{Si}$ & 533 & 912 & 569 & 872 & 994 & 156 & 475 & 126 & 325 & 234 \\
\hline $\mathrm{Ca}$ & 618 & 336 & 619 & 640 & 778 & 143 & 166 & 104 & 237 & 175 \\
\hline $\mathrm{Fe}$ & 477 & 841 & 446 & 1141 & 419 & 146 & 374 & 88 & 317 & 112 \\
\hline $\mathrm{Cu}$ & 19.3 & 32.1 & 22.3 & 61.9 & 6.2 & 6.9 & 15.6 & 4.7 & 32.6 & 2.2 \\
\hline $\mathrm{Zn}$ & 63.8 & 103.2 & 18.7 & 82.6 & 18.0 & 45.0 & 90.7 & 10.3 & 56.2 & 9.9 \\
\hline $\mathrm{Ba}$ & 11.1 & 35.6 & 14.9 & 59.6 & 16.1 & 4.4 & 15.8 & 4.7 & 52.3 & 6.9 \\
\hline $\mathrm{Sn}$ & 4.6 & 8.1 & NA & 34.0 & 1.5 & 2.2 & 4.7 & NA & 32.3 & 1.0 \\
\hline $\mathrm{Sb}$ & 2.6 & 5.2 & NA & 21.2 & 0.8 & 1.1 & 5.1 & NA & 20.7 & 0.5 \\
\hline $\mathrm{Ni}$ & 1.7 & 2.8 & 1.4 & 5.3 & 2.6 & 1.3 & 2.4 & 1.0 & 4.6 & 1.5 \\
\hline V & 4.5 & 4.6 & 2.1 & 2.3 & 4.0 & 3.7 & 3.1 & 1.7 & 2.6 & 2.7 \\
\hline $\mathrm{Cr}$ & 3.0 & 4.6 & 3.2 & 4.7 & 2.5 & 1.3 & 2.0 & 0.8 & 2.1 & 2.0 \\
\hline Mo & 9.3 & 4.1 & 1.7 & NA & 1.8 & 9.7 & 1.7 & 1.5 & NA & 1.7 \\
\hline $\mathrm{Pb}$ & 7.0 & 15.0 & 4.3 & 18.6 & 4.2 & 5.4 & 13.3 & 3.7 & 15.2 & 2.7 \\
\hline $\mathrm{Cd}$ & 0.2 & 0.2 & 0.2 & NA & 0.1 & 0.1 & 0.3 & 0.2 & NA & 0.1 \\
\hline Co & 0.1 & 0.1 & NA & NA & 0.1 & 0.1 & 0.2 & NA & NA & 0.1 \\
\hline As & 0.4 & 1.6 & 0.5 & NA & 0.6 & 0.3 & 0.7 & 0.4 & NA & 0.4 \\
\hline $\mathrm{Se}$ & 0.3 & 1.0 & 0.6 & NA & 0.5 & 0.2 & 0.4 & 0.5 & NA & 0.3 \\
\hline $\mathrm{Ge}$ & 0.2 & 0.1 & NA & NA & 0.6 & 0.2 & 0.1 & NA & NA & 0.6 \\
\hline W & 0.4 & 0.3 & NA & NA & 0.6 & 0.2 & 0.5 & NA & NA & 0.6 \\
\hline $\mathrm{Bi}$ & 0.4 & 0.3 & NA & NA & 0.1 & 0.2 & 0.2 & NA & NA & 0.1 \\
\hline $\mathrm{Br}$ & NA & 10.9 & 4.4 & 19.8 & 5.7 & NA & 7.6 & 3.6 & 10.3 & 3.4 \\
\hline $\mathrm{P}$ & 16.0 & 24.2 & 9.5 & 28.0 & 9.2 & 6.5 & 11.0 & 3.5 & NA & 6.8 \\
\hline $\mathrm{Ti}$ & 16.3 & 25.5 & 13.7 & 30.2 & 24.7 & 4.9 & 14.5 & 3.5 & 14.3 & 8.2 \\
\hline $\mathrm{Mn}$ & 9.9 & 14.3 & 7.1 & 16.3 & 7.1 & 4.6 & 8.8 & 2.1 & 8.5 & 2.2 \\
\hline $\mathrm{Rb}$ & 0.4 & 5.6 & 1.7 & 1.6 & 1.7 & 0.2 & 2.7 & 0.7 & 0.9 & 0.8 \\
\hline $\mathrm{Sr}$ & 2.1 & 3.6 & 2.1 & 13.0 & 3.1 & 0.6 & 1.1 & 0.8 & 13.5 & 1.0 \\
\hline$Y$ & 0.2 & 6.2 & 0.7 & NA & 0.7 & 0.2 & 1.7 & 0.7 & NA & 0.7 \\
\hline $\mathrm{Zr}$ & 6.7 & 5.9 & 2.2 & NA & 1.7 & 5.5 & 2.3 & 0.8 & NA & 1.1 \\
\hline $\mathrm{Li}$ & 0.2 & 0.7 & NA & NA & 0.3 & 0.1 & 0.5 & NA & NA & 0.1 \\
\hline $\mathrm{Nb}$ & 0.4 & 0.5 & NA & NA & 0.5 & 0.2 & 0.5 & NA & NA & 0.3 \\
\hline $\mathrm{Ga}$ & 0.1 & 0.2 & NA & NA & 0.2 & 0.1 & 0.2 & NA & NA & 0.1 \\
\hline Th & 0.1 & 0.01 & NA & NA & 0.2 & 0.1 & 0.1 & NA & NA & 0.2 \\
\hline $\mathrm{La}$ & 0.2 & 0.3 & 0.5 & NA & 0.3 & 0.1 & 0.2 & 0.3 & NA & 0.2 \\
\hline $\mathrm{Ce}$ & 0.4 & 0.8 & 0.5 & NA & 0.4 & 0.2 & 0.5 & 0.3 & NA & 0.3 \\
\hline
\end{tabular}


Table 1. Continued.

\begin{tabular}{|c|c|c|c|c|c|c|c|c|c|c|}
\hline \multirow[b]{2}{*}{$n g m^{-3}$} & \multicolumn{5}{|c|}{$\mathrm{PM}_{10}$} & \multicolumn{5}{|c|}{$\mathrm{PM}_{2.5}$} \\
\hline & BCN-UB & POR-TR & FI-UB & MLN-UB & ATH-SUB & BCN-UB & POR-TR & FI-UB & MLN-UB & ATH-SUB \\
\hline & BCN-UB & POR-TR & FI-UB & MLN-UB & ATH-SUB & BCN-UB & POR-TR & FI-UB & MLN-UB & ATH-SUB \\
\hline Secondary inorganic & 4578 & 5072 & 3448 & 13147 & 5869 & 3316 & 3902 & 2724 & 9871 & 4004 \\
\hline Primary & 7818 & 16966 & 7382 & 9851 & 6806 & 3574 & 10767 & 3748 & 7531 & 1884 \\
\hline $\mathrm{POM}+\mathrm{EC}$ & 2270 & 8257 & 4438 & 5918 & 853 & 2051 & 8586 & 3157 & 5795 & 663 \\
\hline Secondary & 8619 & 9901 & 9734 & 25832 & 12081 & 6873 & 8746 & 9013 & 17876 & 9014 \\
\hline Sea salt & 1494 & 4381 & 651 & 733 & 1655 & 380 & 1243 & 106 & 448 & 237 \\
\hline Mineral dust & 4054 & 4341 & 2273 & 3790 & 4236 & 1144 & 2181 & 486 & 1286 & 986 \\
\hline Unexplained & 6334 & 7792 & 1846 & 6188 & 1967 & 4762 & 6751 & 657 & 4449 & 966 \\
\hline Reconstructed & 1692 & 26728 & 17050 & 31886 & 17815 & 10239 & 19929 & 12556 & 25680 & 10037 \\
\hline
\end{tabular}

that the sampling year was particularly rainy at most of the study sites, including Florence. The daily $\mathrm{PM}_{10}$ and $\mathrm{PM}_{2.5}$ WHO threshold (50 and $25 \mu \mathrm{g} \mathrm{m}^{-3}$, respectively) was exceeded only in MLN-UB and POR-TR.

As shown by Fig. S3, seasonal trends for $\mathrm{PM}_{10}$ at the five AIRUSE cities were very different. ATH-SUB was characterized by higher spring-summer and lower autumnwinter $\mathrm{PM}_{10}$ levels, probably due to the higher African dust influence in the warm seasons. A similar but much smoother trend was observed for BCN-UB. For POR-TR, the highest levels were recorded in summer and the lowest in spring. At MLN-UB, lower levels were recorded in spring and summer, when $\mathrm{PM}_{10}$ levels reached similar levels to BCN-UB, FIUB or ATH-SUB; however, in autumn and winter, levels at MLN-UB were higher by a factor of more than 2 with respect to the other seasons and most of the other cities. This is due to the aforementioned atmospheric stagnation features of the Po Valley that favoured the accumulation of intensive winter PM emissions. At FI-UB a similar trend was observed, but with a less pronounced winter increase than that described for MLN-UB. In fact, Florence is also located in a closed basin (the Arno River valley), which is characterized by stagnant conditions during the cold season. $\mathrm{PM}_{2.5}$ levels followed similar seasonal patterns to those described above for $\mathrm{PM}_{10}$ at each city.

\subsection{PM chemical composition}

\subsubsection{EC, OC and OM}

EC is a tracer of emissions from road traffic, mainly from diesel vehicles (Querol et al., 2013); it is a carrier of highly health-relevant organic species (WHO, 2012). Mean EC concentrations reached $1.1 \mu \mathrm{g} \mathrm{m}^{-3}$ in $\mathrm{PM}_{10}$ at the UB sites of BCN and FI and $1.9 \mu \mathrm{g} \mathrm{m}^{-3}$ at the UB site of MLN (Fig. 1). At the SUB site of ATH, EC levels were lower $\left(0.4 \mu \mathrm{g} \mathrm{m}^{-3}\right.$ in $\mathrm{PM}_{10}$, Fig. 1) due to the higher distance from avenues with high traffic load, but also due to the lower proportion of diesel vehicles in the fleet of ATH compared to the other three cities. Until 2012, the use of diesel for private cars was not allowed in this city.
As expected, levels of EC at traffic sites were higher than at UB sites by a factor ranging from 3.6 to 4.9 . EC levels recorded for $\mathrm{PM}_{10}$ are very close to those of $\mathrm{PM}_{2.5}$ $\left(\mathrm{PM}_{2.5} / \mathrm{PM}_{10}\right.$ ratios within 0.9 to 1.0$)$, pointing to the very fine size of the EC-bearing particles.

$\mathrm{OM}$ was calculated by multiplying $\mathrm{OC}$ by a factor accounting for non-C atoms which may change according to location and existing sources (Turpin and Huntzicker, 1995). This factor ranged from 1.2 (at the POR-TR site due its proximity to traffic emissions, Pio et al., 2011) to $1.7-1.8$ (rest of the sites, Minguillón et al., 2011, and Mohr et al., 2012). Mean levels of OM (Fig. 1) reached 5.0 and $5.5 \mu \mathrm{g} \mathrm{m}^{-3}$ in $\mathrm{PM}_{10}$ at the BCN-UB and ATH-SUB sites, respectively, but increased up to 9.6 and $15.4 \mu \mathrm{g} \mathrm{m}^{-3}$ at FI-UB and MLN-UB. At POR-TR, the mean level of OM was $7.9 \mu \mathrm{g} \mathrm{m}^{-3}$. OM also has a fine grain size since $\mathrm{PM}_{2.5} / \mathrm{PM}_{10}$ ratios for this component ranged from 0.7 to 1.0. $\mathrm{OM} / \mathrm{EC}$ ratios for $\mathrm{PM}_{10}$ ranged from 1.6 at POR-TR, reaching values of 4.4 at the UB site of BCN, 8.2 and 8.7 at the UB sites of MLN and FI, and 13 at the SUB site of ATH. This ratio results from the influence of both the proximity to the emission sources and the biomass burning. Thus, primary diesel soot is characterized by an $\mathrm{OM} / \mathrm{EC}$ ratio close to 1.0 , whereas a higher ratio indicates a major relative abundance of secondary OM, due to a longer distance from emission hotspots (from TR to UB to SUB) and/or a higher contribution from biomass burning to PMx levels, since OM/EC from biomass burning is much higher (Puxbaum et al., 2007). Also, biogenic emissions can increase the $\mathrm{OM} / \mathrm{EC}$ ratio.

Levels of OM + EC accounted for around 27-30\% of the $\mathrm{PM}_{10}$ load at the UB and SUB sites, with the exception of FI and MLN (45-58\%). At POR-TR this contribution increased to $37 \%$. In $\mathrm{PM}_{2.5}$ the $\mathrm{OM}+\mathrm{EC}$ load increased as compared with $\mathrm{PM}_{10}$ and ranged from 37 to $69 \%$ of the $\mathrm{PM}_{2.5}$ mass. This is due mainly to the decrease in mineral dust and sea salt in $\mathrm{PM}_{2.5}$ when compared with $\mathrm{PM}_{10}$.

The higher levels of OM recorded at MLN, FI and, partially, at POR, are probably the result of a high contribution to $\mathrm{PM}_{10}$ levels from biomass burning (BB). This is also confirmed by the high OM/EC ratios. In the case of MLN the 

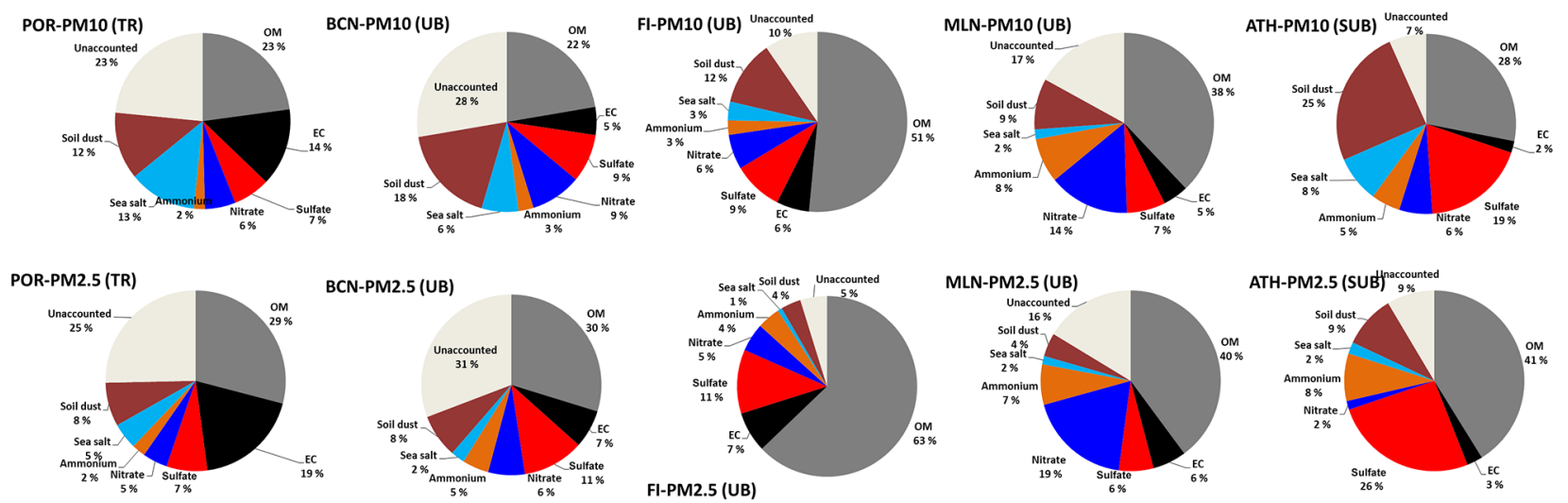

Figure 1. Mass closure of $\mathrm{PM}_{10}$ and $\mathrm{PM}_{2.5}$ chemical speciation data for the five AIRUSE cities.

frequent atmospheric stagnation episodes also favour the formation of secondary OM as also described later for nitrate. To a lesser extent this also applies for FI, where stagnant conditions are common during winter.

\subsubsection{Sea salt}

Sea salt was calculated based on the main composition of sea spray (ss) as the sum $\mathrm{ssNa}+\mathrm{Cl}+$ $\mathrm{ssMg}+\mathrm{ssK}+\mathrm{ssCa}+\mathrm{ssSO}_{4}^{2-}$, where $\mathrm{ssNa}=\mathrm{Na}-\mathrm{nssNa}$, $\mathrm{nssNa}=0.348 \cdot \mathrm{Al}, \mathrm{ssMg}=0.119 \cdot \mathrm{ssNa}, \mathrm{ssK}=0.037 \cdot \mathrm{ssNa}$, $\mathrm{ssCa}=0.038 \cdot \mathrm{ssNa}$ and $\mathrm{ssSO}_{4}=0.253 \cdot \mathrm{ssNa}$ (Calzolai et al., 2015). Mean levels of sea salt (Fig. 1) in $\mathrm{PM}_{10}$ reached $0.6-0.7 \mu \mathrm{g} \mathrm{m}^{-3}$ at the inland Italian cities (FI and MLN, 2$3 \%$ of the $\mathrm{PM}_{10}$ load) and $1.5-1.7 \mu \mathrm{g} \mathrm{m}^{-3}$ (7-8\% of the $\mathrm{PM}_{10}$ load) at the Mediterranean coastal sites. However, at the Atlantic site (POR), much higher levels were recorded ( $4.3 \mu \mathrm{g} \mathrm{m}^{-3}$ in $\mathrm{PM}_{10}, 13 \%$ of the $\mathrm{PM}_{10}$ load at the TR site).

As expected, due to the coarse mass size distribution of sea salt, levels were reduced by $71-86 \%$ in $\mathrm{PM}_{2.5}$ with respect to $\mathrm{PM}_{10}$, with the exception of MLN, where levels of sea salt were only reduced by around $38 \%$ in $\mathrm{PM}_{2.5}$.

\subsubsection{Mineral dust}

Mineral dust (or soil dust) was calculated based on average crust composition (Nava et al., 2012) as $1.15 \cdot(3.79 \cdot \mathrm{Al}+2.14 \cdot \mathrm{Si}+1.67 \cdot \mathrm{Ti})^{-}$. In the case of the quartz filter, a value of 3 for ratio $\mathrm{SiO}_{2} / \mathrm{Al}_{2} \mathrm{O}_{3}$ was used. Mineral dust at UB sites reached around $2.3 \mu \mathrm{g} \mathrm{m}^{-3}$ as the annual mean in FI-UB and $3.8-4.2 \mu \mathrm{g} \mathrm{m}^{-3}$ at the UB and SUB sites of BCN, MLN and ATH (Fig. 1). These levels account for 18 and $25 \%$ of the $\mathrm{PM}_{10}$ mass at $\mathrm{BCN}$ and ATH and 12 and $10 \%$ at FI and MLN, respectively. At the POR-TR site, mineral dust accounts for $12 \%$ of the $\mathrm{PM}_{10}$.

As also expected from the coarse mode of occurrence of mineral dust, levels of this PM component were much lower in $\mathrm{PM}_{2.5}$, down to $20-49 \%$ of the $\mathrm{PM}_{10}$ levels. The contri- bution of mineral dust reached from 4 to $10 \%$ of $\mathrm{PM}_{2.5}$ for all sites.

\subsubsection{Sulfate and nitrate}

There is a marked geographical variability, with increased levels of sulfate from FI-BCN to POR-MLN to ATH (1.72.0 to $2.4-3.0$ to $3.7 \mu \mathrm{g} \mathrm{m}^{-3}$ in $\mathrm{PM}_{10}$ and $1.5-1.7$ to $1.9-2.0$ to $2.9 \mu \mathrm{g} \mathrm{m}^{-3}$ in $\mathrm{PM}_{2.5}$, Fig. 1). This is probably due to the influence of the use of coal and petroleum coke/fuel oil for power generation in and/or around the high sulfate regions of this study, but it may also be caused by the influence of $\mathrm{SO}_{2}$ emissions from petrochemical plants. In the case of POR, when the site is under the influence of north-westerly winds, one of the major sources of sulfate could be the Porto Refinery (10 km away from the sampling site), which began operating in 1970. It is a crude oil industrial processing plant that has an annual installed capacity of 4.5 million ton and produces a wide range of products including fuels, lubricants, aromatics (BTX) for the petrochemical industry, industrial solvents and petroleum waxes. Emissions from shipping in the harbour may represent another possible source. As expected from the fine mode of occurrence of ammonium sulfate $\left(\left(\mathrm{NH}_{4}\right)_{2} \mathrm{SO}_{4}\right.$ or $\left.\mathrm{NH}_{4} \mathrm{HSO}_{4}\right), 76$ to $85 \%$ of the sulfate in $\mathrm{PM}_{10}$ is present in $\mathrm{PM}_{2.5}$.

Levels of nitrate in $\mathrm{PM}_{10}$ show a less marked spatial variability, with the exception of MLN, with mean annual levels reaching 1.2 (FI-ATH) to 2.0 (POR-BCN) $\mu \mathrm{g} \mathrm{m}^{-3}$ and $6.0 \mu \mathrm{g} \mathrm{m}^{-3}$ in MLN. This marked difference between MLN and the rest of the other AIRUSE regions is mainly due to the specific meteorological and emission patterns of the Po Valley. In this case, it coincides with a large urban and industrial agglomeration (with the associated road traffic), with the consequent elevated atmospheric emissions and a peculiar meteorology favouring frequent and marked thermal inversions that cause the accumulation of pollutants and the formation of high levels of ammonium nitrate $\left(\mathrm{NH}_{4} \mathrm{NO}_{3}\right)$ from the high anthropogenic $\mathrm{NO}_{x}$ and $\mathrm{NH}_{3}$ emissions and 
the coldest temperature in winter among AIRUSE cities. In particular, high $\mathrm{NH}_{3}$ levels, emitted from agricultural and animal husbandry activities, can be transported from the southern part of the Po Valley to the urbanized northern part, inducing ammonium nitrate formation. On the other hand, the relatively coarse mode of nitrate is noticeable in all cases, since levels in $\mathrm{PM}_{2.5}$ are generally 50-60\% lower than in $\mathrm{PM}_{10}$, with the exception of MLN by $40 \%$ and the ATHSUB area by $85 \%$. These large fractions of coarse nitrate are probably due to the high temperatures and dry conditions reached in summer in the study regions. Especially at higher temperatures, $\mathrm{NH}_{4} \mathrm{NO}_{3}$ dissociate into gaseous $\mathrm{HNO}_{3}$ and $\mathrm{NH}_{3}$, and in turn a fraction of this $\mathrm{HNO}_{3}$ may react with $\mathrm{NaCl}$ or $\mathrm{CaCO}_{3}$ to give coarse $\mathrm{NaNO}_{3}$ or $\mathrm{Ca}\left(\mathrm{NO}_{3}\right)_{2}$. This accounts for the large differences observed for nitrate in the coarse and fine size fractions at MLN and ATH, with $60 \%$ of nitrate residing in the fine aerosol at the first site and only $15 \%$ at the latter. The hypothesis of a temperature-driven behaviour of nitrate is reinforced by the seasonal trends of the ratios between fine $\left(\mathrm{PM}_{2.5}\right)$ nitrate and $\mathrm{PM}_{10}$ nitrate: most of the nitrate, i.e. $60-80 \%$ of it, is in $\mathrm{PM}_{2.5}$ during autumn and winter, while the percentage drastically decreases during spring-summer, down to roughly $15 \%$. Seasonal trends are less and less pronounced when passing from cities with a continental climate such as FI (and MLN) to coastal ones with a mild climate such as POR and BCN, and are not visible in ATH, with a warmer climate.

The contribution of sulfate, nitrate and ammonium (secondary inorganic aerosols, SIA) to the $\mathrm{PM}_{10}$ load reaches $15-21 \%$ of $\mathrm{PM}_{10}$ in BCN-UB, POR-TR and FI-UB, but 30$31 \%$ at MLN-UB and ATH-SUB. In spite of the prevailing fine mode of these PM components, the contribution of SIA to the $\mathrm{PM}_{2.5}$ load remains similar to that of $\mathrm{PM}_{10}$, with 1323 and $31-37 \%$ for the above groups of sites. The latter two cities (MLN and ATH) are both characterized by similarly high SIA loads, but due to different causes, whereas at MLN SIA is dominated by ammonium nitrate; in ATH ammonium sulfate prevails.

The ion balances between cations and anions of the daily $\mathrm{PM}_{10}$ and $\mathrm{PM}_{2.5}$ samples collected at the five AIRUSE cities are reported in Fig. S4. The results showed that there was a neutralization of the acidic components of the $\mathrm{PM}_{10}$ and $\mathrm{PM}_{2.5}$ in all cases, with the exception of FI in the $\mathrm{PM}_{2.5}$ fraction. Thus, the balances range from anions $=0.82$. cations $\left(\mathrm{BCN}, R^{2}=0.72\right)$ to anions $=1.0 \cdot$ cations $\left(\mathrm{POR}, R^{2}=0.96\right)$. A slope lower than 1.0 means that there is a cation load in excess, probably due to the occurrence of $\mathrm{Ca}$ - and $\mathrm{Mg}$-bearing carbonate minerals (Alastuey et al., 2005). This is expected to occur specially during African dust episodes (see low anion/cation samples present in the balance of BCN in Fig. S4). In the case of FI $\mathrm{PM}_{2.5}$ samples, the regression fits with anions $=1.12 \cdot$ cations $\left(R^{2}=0.95\right)$, which points to a slightly acidic character of the PM samples with a fraction of $12 \%$ of the anionic species being present as acids. However, con- clusions on aerosol $\mathrm{pH}$ cannot be conclusive given that ionic balance and molar ratio methods have been recently criticized (Hennigan et al., 2015).

\subsubsection{Secondary vs. primary PM}

The amount of secondary aerosol was roughly estimated at each site as

secondary aerosols : $\mathrm{NO}_{3}^{-}+\mathrm{SO}_{4}^{2-}+\mathrm{NH}_{4}^{+}$

$$
+(\mathrm{OC}-(\mathrm{EC} \cdot a)) \cdot b \text {, }
$$

where $a$ expresses the primary OC/EC ratio (averaged among existing sources, and varying between 0.7 and 2.2; Pio et al., 2011) and $b$ accounts for the non-C atoms in secondary aerosol mass (varying between 1.6 and 2.1; Aiken et al., 2008). Figure 2 shows that for $\mathrm{PM}_{10}$, at the UB and SUB sites the secondary fraction dominated the $\mathrm{PM}_{10}$ mass by contributing from $53 \%$ (BCN) to $71 \%$ (MLN), whereas at POR-TR the primary contribution prevailed (60-63\%). For the calculation of the secondary and primary fractions, all values are normalized by the sum of reconstructed PM mass. It is very important to be taken into account this high load of secondary PM mass in designing air quality plans, since these components are formed in the atmosphere from organic and inorganic gaseous precursors. The organic and inorganic secondary contributions to $\mathrm{PM}_{10}$ are very well balanced (close to $50-50 \%$ in most cases), but not in the case of FI-UB, where $65 \%$ of the secondary $\mathrm{PM}_{10}$ load is from organic aerosols (Fig. 2), probably indicating a relative contribution from biomass burning compared with the other sources. The contributions of secondary aerosols to $\mathrm{PM}_{2.5}$ increase when compared with $\mathrm{PM}_{10}$ due to the lower contributions of dust and sea salt to the fine fraction. This secondary contribution then ranged from $66 \%(\mathrm{BCN})$ to $82 \%(\mathrm{ATH})$ at the UB and SUB sites and $37 \%$ at POR-TR (Fig. 2).

\subsubsection{Biomass burning tracers}

Levels of levoglucosan and $\mathrm{K}$ are considered tracers for biomass burning (Fine et al., 2001; Gonçalves et al., 2010; Nava et al., 2014). In fact, levoglucosan is a sugar emitted into the atmosphere exclusively by breaking cellulose chains during biomass burning. Levoglucosan levels varied by 1 order of magnitude: 20 (BCN), 37 (ATH), 255 (FI), 274 (MLN) and 387 (POR) ng m ${ }^{-3}$ in $\mathrm{PM}_{2.5}$ (Table 1), reflecting a very clear difference in the impact of biomass burning on air quality across southern European cities. The values obtained should be considered minimum levels because it is well known that levoglucosan may be degraded in highly oxidizing environments (Simoneit et al., 1999). This impact is mostly due to differences in using biomass burning for domestic purposes, but in POR and MLN, peak events were also detected in summer as a consequence of the impact of the emissions of forest fires and/or agricultural fires. The decreasing impact of biomass burning on $\mathrm{PM}_{2.5}$ levels when 

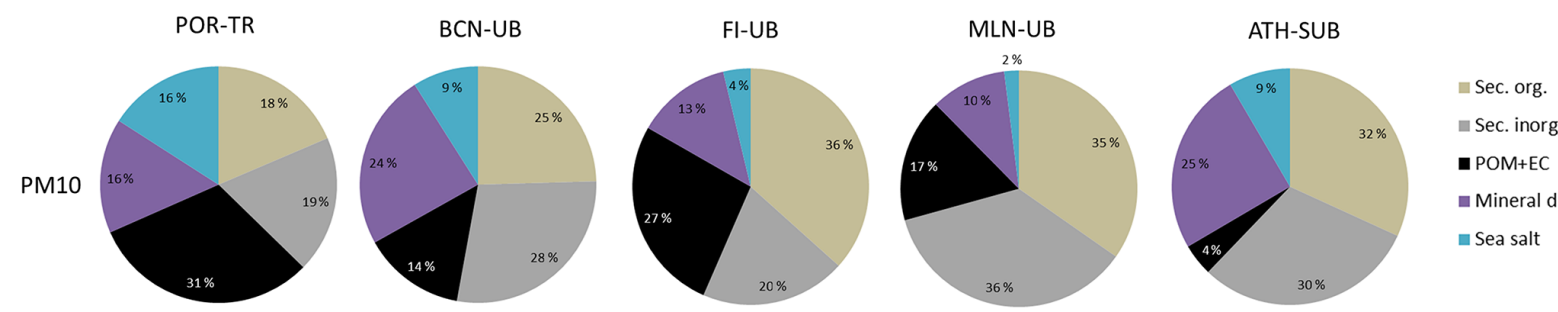

$\varpi$ Sec. inorg.

- $\mathrm{POM}+\mathrm{EC}$

Mineral dust

- Sea salt
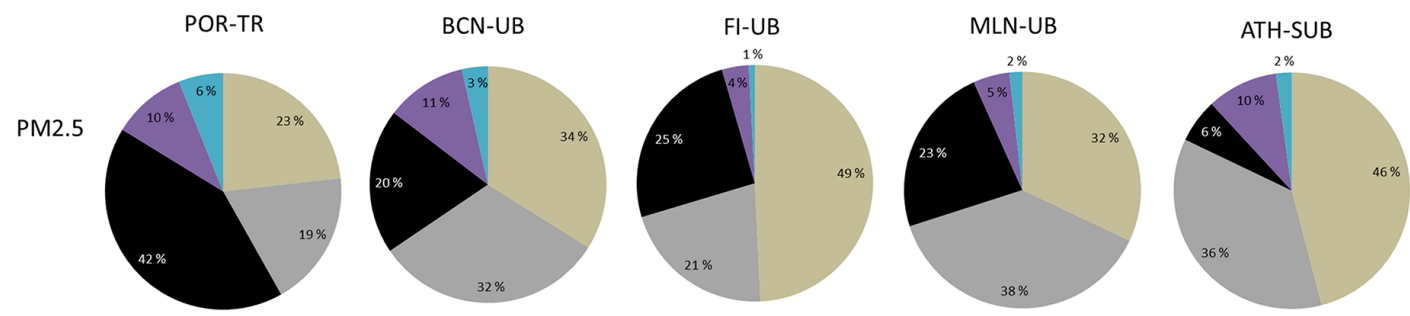

Figure 2. Secondary and primary $\mathrm{PM}$ components of the mean $\mathrm{PM}_{10}$ and $\mathrm{PM}_{2.5}$ levels at the five AIRUSE cities.

passing from MLN to FI to POR to ATH and to BCN is clearly demonstrated by the time series of daily levels of levoglucosan (Table 1). The lower values for Athens can also be attributed to the suburban character of the site. On the other hand, levels of $\mathrm{K}$ in the fine fraction $\left(\mathrm{PM}_{2.5}\right)$ may also increase as a consequence of the influence of inorganic biomass burning ash contributions to the PM load. In this case, the differences are also evident but less marked than for levoglucosan: 87 (BCN), 115 (ATH), 172 (FI), 345 (POR) and 303 (MLN) ng $\mathrm{m}^{-3}$ in $\mathrm{PM}_{2.5}$ (Table 1). This lower differentiation is due to the fact that $\mathrm{K}$ may be partially supplied by mineral dust (clay minerals and feldspars) and probably by specific industrial sources.

\subsubsection{Trace elements}

Levels of $\mathrm{Ti}, \mathrm{Mn}, \mathrm{Sr}, \mathrm{Cu}, \mathrm{Zn}, \mathrm{Sn}, \mathrm{Ni}, \mathrm{Ba}$ and $\mathrm{Pb}$ are higher in MLN, and in some cases in POR $(\mathrm{Zn}, \mathrm{Ba}, \mathrm{Pb}, \mathrm{Cd})$, when compared with the other sites. Most of these elements are usually related to metallurgy and heavy industry emissions.

Levels of As and Se (generally used as tracers of coal combustion) were relatively higher in POR and ATH, pointing to a possible local, regional or long-range transport influence of emissions from coal combustion sources on air quality. Northern Greece has a number of large coal-fired power plants that may partly account for these concentration levels. Transport of emissions from coal-fired power plants from the Balkans, eastern Europe and Turkey may also contribute. In the case of POR, the coal power plant located $15 \mathrm{~km}$ southeast of Porto was deactivated in December 2004, and there was no coal combustion activity in the area during the campaign. The closest coal-fired power plant is located in northwestern Spain, at around $300 \mathrm{~km}$ from Porto. It is possible that other industrial sources of As and Se (ceramic, glass, and cement production, among others) may also contribute to increased levels of these elements.
Levels of $\mathrm{Cu}, \mathrm{Sb}, \mathrm{Ba}$ and $\mathrm{Sn}$ were relatively higher in PORTR as compared with UB sites, due to their association with non-exhaust vehicle emissions including brake and tyre wear (Gietl et al., 2010).

Levels of V were 4 to 2 times higher in the cities with a harbour (POR, BCN and $\mathrm{ATH}$ ), pointing to the fact that, in spite of the possible use of fuel oil or petroleum coke for power generation or industrial processes, shipping emissions are the main sources of these heavy oil combustion tracers in these AIRUSE cities.

Rare earth elements (REEs) usually occur in mineral dust, and the ratio $\mathrm{Ce} / \mathrm{La}$ in the earth's crust is close to 2 . The marked decrease in this ratio may be used as a tracer of the influence of emission from La-based oil cracking in petrochemical plants. In this study most of the cities have a ratio $\mathrm{Ce} / \mathrm{La}$ close to 2.0, with the exception of FI and ATH (1.0 and 1.3), this indicating the possible influence of this type of emission at both sites, although other sources of La cannot be discounted. In Athens the refinery is located $15 \mathrm{~km}$ northwest of the city centre, while for Florence, about $90 \mathrm{~km}$ away to the west, in the province of Livorno.

The unaccounted mass of PM is that resulting from the difference in the gravimetric measurements of the filters and the sum of all the components determined by chemical analysis. This unaccounted mass is usually attributed to water molecules contained in potential remaining moisture, and crystallization and formation water (water molecules in the structure of specific chemical species). In this study the unaccounted mass was higher at BCN-UB and POR-TR (23 and $31 \%$ for $\mathrm{PM}_{10}$ and $\mathrm{PM}_{2.5}$, respectively) and similarly lower (5-14\%) at all the other sites.

\subsubsection{Source apportionment results}

For each AIRUSE station, the best PMF solution was found when combining $\mathrm{PM}_{10}$ and $\mathrm{PM}_{2.5}$ samples in a single input 
Table 2. Summary of input species, identified factors and constraints for city-specific PMF analyses.

\begin{tabular}{|c|c|c|c|}
\hline Station & Input species & Sources/factors & Constraints \\
\hline BCN-UB & $\begin{array}{l}\mathrm{EC}, \mathrm{OC}, \mathrm{Al}, \mathrm{Ca}, \mathrm{Fe}, \mathrm{K} \\
\mathrm{Mg}, \mathrm{Na}, \mathrm{Cl}^{-}, \mathrm{Ti}, \mathrm{V}, \mathrm{Cr}, \mathrm{Mn}, \\
\mathrm{Ni}, \mathrm{Cu}, \mathrm{Zn}, \mathrm{Li}, \mathrm{Ga}, \mathrm{As}, \mathrm{Se} \\
\mathrm{Rb}, \mathrm{Sr}, \mathrm{Cd}, \mathrm{Sn}, \mathrm{Sb}, \mathrm{Ba}, \mathrm{La} \\
\mathrm{Ce}, \mathrm{Pb}, \mathrm{S}, \mathrm{NH}_{4}^{+}, \mathrm{NO}_{3}^{-}\end{array}$ & $\begin{array}{l}\text { vehicle exhaust (VEX), vehicle non-exhaust } \\
\text { (NEX), secondary nitrate (SNI), mineral } \\
\text { (MIN), secondary sulfate and organics (SSO), } \\
\text { industrial (IND), heavy oil combustion (HOC) } \\
\text { and aged sea salt (SEA) }\end{array}$ & $\begin{array}{l}\text { - Pulling the difference of source contributions } \\
\text { between } \mathrm{PM}_{10} \text { and } \mathrm{PM}_{2.5} \text { to zero. } \\
\text { - Pulling the chemical profile ( } 24 \text { species) of the } \\
\text { NEX source towards the experimental profile of } \\
\text { road dust obtained in Barcelona (Amato et al., } 2009 \text { ). } \\
-\mathrm{Pulling} \text { the ratios } \mathrm{Cl}^{-} / \mathrm{Na}, \mathrm{S} / \mathrm{Na}, \mathrm{K} / \mathrm{Na}, \mathrm{Ca} / \mathrm{Na} \text {, } \\
\mathrm{Mg} / \mathrm{Na} \text { of the } \mathrm{SEA} \text { profile to the literature values of } \\
1.8,0.084,0.037,0.038 \text { and } 0.119 \text {, respectively. }\end{array}$ \\
\hline FI-UB & $\begin{array}{l}\text { EC, OC, levoglucosan, } \mathrm{Si} \\
\mathrm{Al}, \mathrm{Ca}, \mathrm{Fe}, \mathrm{K}, \mathrm{Mg}, \mathrm{Na}, \mathrm{Cl} \\
\mathrm{Ti}, \mathrm{V}, \mathrm{Cr}, \mathrm{Mn}, \mathrm{Ni}, \mathrm{Cu}, \mathrm{Zn} \\
\mathrm{As}, \mathrm{Se}, \mathrm{Rb}, \mathrm{Sr}, \mathrm{Cd}, \mathrm{Ba}, \mathrm{Pb} \\
\mathrm{S}, \mathrm{Br}, \mathrm{NH}_{4}^{+}, \mathrm{NO}_{3}^{-}\end{array}$ & $\begin{array}{l}\text { aged sea salt (SEA), Saharan dust (SAH), } \\
\text { secondary sulfate and organics (SSO), Vehicle } \\
\text { non-exhaust (NEX), biomass burning (BB), } \\
\text { secondary nitrate (SNI), vehicle exhaust } \\
\text { (VEX), heavy oil combustion (HOC), local } \\
\text { dust (LDU) and fresh sea salt (FSS). }\end{array}$ & $\begin{array}{l}\text { - Pulling down the } \mathrm{EC} \text { and } \mathrm{OC} \text { contributions in the } \\
\text { SAH source profile and the } \mathrm{NO}_{3}^{-} \text {contribution in } \\
\text { the sea salt profile. } \\
\text { - Pulling down the } \mathrm{SAH} \text { source contributions during } \\
\text { a period (1-22 July 2013) when the advection of desert } \\
\text { dust can be excluded on the basis of all the used } \\
\text { transport models. } \\
\text { - Pulling the difference of source contributions } \\
\text { between } \mathrm{PM}_{10} \text { and } \mathrm{PM}_{2.5} \text { to zero, only for those } \\
\text { days and sources where } \mathrm{PM}_{2.5} \text { contribution was } \\
\text { higher than } \mathrm{PM}_{10} \text { contribution in the base run } \\
\text { solution ( } 55 \text { days). }\end{array}$ \\
\hline ATH-SUB & $\begin{array}{l}\mathrm{EC}, \mathrm{OC}, \mathrm{Si}, \mathrm{Al}, \mathrm{Ca}, \mathrm{Fe}, \mathrm{K} \\
\mathrm{Mg}, \mathrm{Na}, \mathrm{Cl}, \mathrm{Ti}, \mathrm{V}, \mathrm{Mn}, \mathrm{Ni} \\
\mathrm{Cu}, \mathrm{Zn}, \mathrm{As}, \mathrm{Sr}, \mathrm{Cd}, \mathrm{Sb}, \mathrm{Pb} \\
\mathrm{S}, \mathrm{Br}, \mathrm{NH}_{4}^{+}, \mathrm{NO}_{3}^{-}\end{array}$ & $\begin{array}{l}\text { heavy oil combustion (HOC), vehicle exhaust } \\
\text { (VEX), secondary nitrate (SNI), mineral } \\
\text { (MIN), vehicle non-exhaust (NEX), biomass } \\
\text { burning (BB), secondary sulfate and organics } \\
\text { (SSO) and fresh sea salt (SEA). }\end{array}$ & $\begin{array}{l}\text { - For the cases with daily } \mathrm{PM}_{2.5} \text { contribution } \\
\text { significantly higher than } \mathrm{PM}_{10} \text { contribution, } \\
\mathrm{PM}_{2.5} \text { contribution was either set to zero (two cases) } \\
\text { or pulled down maximally (four cases), depending on } \\
\text { the respective } \mathrm{PM}_{10} \text { contribution. } \\
\text { - OC was pulled up in the } \mathrm{HOC} \text { factor. } \\
- \text { OC was set to have the original value of the } \\
\text { unconstrained solution in the BB factor }\end{array}$ \\
\hline POR-TR & $\begin{array}{l}\text { EC, OC, levoglucosan, } \mathrm{Si} \text {, } \\
\mathrm{Al}, \mathrm{Ca}, \mathrm{Fe}, \mathrm{K}, \mathrm{Mg}, \mathrm{Na}, \mathrm{Cl}^{-} \text {, } \\
\mathrm{Ti}, \mathrm{V}, \mathrm{Cr}, \mathrm{Mn}, \mathrm{Ni}, \mathrm{Cu}, \mathrm{Zn}, \\
\mathrm{Li}, \mathrm{As}, \mathrm{Rb}, \mathrm{Cd}, \mathrm{Sn}, \mathrm{Sb}, \mathrm{La}, \\
\mathrm{Ce}, \mathrm{Ba}, \mathrm{Pb}, \mathrm{S}, \mathrm{Br}, \mathrm{NH}_{4}^{+}, \\
\mathrm{NO}_{3}^{-}\end{array}$ & $\begin{array}{l}\text { biomass burning (BB), Secondary nitrate } \\
\text { (SNI), heavy oil and secondary sulfate } \\
\text { (HOS), mineral (MIN), sea salt (SEA), } \\
\text { industrial (IND), vehicle non-exhaust (NEX), } \\
\text { and vehicle exhaust (VEX). }\end{array}$ & $\begin{array}{l}\text { - Pulling the difference of source contributions } \\
\text { between } \mathrm{PM}_{10} \text { and } \mathrm{PM}_{2.5} \text { to zero, only for those } \\
\text { days and sources where } \mathrm{PM}_{2.5} \text { contribution was } \\
\text { higher than } \mathrm{PM}_{10} \text { contribution in the base run } \\
\text { solution. }\end{array}$ \\
\hline MLN-UB & $\begin{array}{l}\mathrm{EC}, \mathrm{OC}, \text { levoglucosan, } \mathrm{Si} \\
\mathrm{Al}, \mathrm{Ca}, \mathrm{Fe}, \mathrm{K}, \mathrm{Mg}^{2+}, \mathrm{Na}^{+} \\
\mathrm{Cl}, \mathrm{Ti}, \mathrm{V}, \mathrm{Cr}, \mathrm{Mn}, \mathrm{Ni}, \mathrm{Cu} \\
\mathrm{Zn}, \mathrm{Rb}, \mathrm{Pb}, \mathrm{S}, \mathrm{Br}, \mathrm{NH}_{4}^{+} \\
\mathrm{NO}_{3}^{-}\end{array}$ & $\begin{array}{l}\text { vehicle exhaust (VEX), vehicle non-exhaust } \\
\text { (NEX), mineral dust (MIN), industrial (IND), } \\
\text { Aged sea salt (SEA), biomass burning (BB), } \\
\text { secondary nitrate (SNI) and heavy oil } \\
\text { combustion and secondary sulfate (HOS). }\end{array}$ & $\begin{array}{l}\text { - Setting to zero the presence of levoglucosan in } \\
\text { VEX and SEA factors. } \\
\text { - Pulling down maximally the presence of } \mathrm{Na}^{+} \text {in the } \\
\text { SNI factor. } \\
\text { - In the SEA profile, pulling the ratio } \mathrm{Cl} / \mathrm{Na}^{+} \text {to the } \\
\text { literature value of } 1.8 \text {. }\end{array}$ \\
\hline
\end{tabular}

matrix for PMF. This method is not new, as it was already proven to increase considerably the statistical significance of the analysis, although it assumes that the chemical profiles of sources do not vary between $\mathrm{PM}_{2.5}$ and $\mathrm{PM}_{10}$ (Amato et al., 2009). Depending on the site, different constraints were added into the PMF model (Paatero and Hopke, 2008), in order to reduce rotational ambiguity and drive the iterations towards a more realistic solution. Auxiliary equations were therefore introduced by means of the USEPA software, and included both physical and chemical constraints. Table 2 summarizes the constraints used in each case, as well as the increment of $\mathrm{d} Q$ (Amato et al., 2009), i.e. the increase in the object function due to the use of auxiliary equations, which in all cases were accomplished with a total increase in $\mathrm{d} Q$ within 3-19\%.
The distribution of residuals, G-space plots, Fpeak values and $Q$ values was explored for solutions with a number of factors varying between 6 and 11 (US EPA, 2014). Table 2 also lists the factors/source finally identified in each case, which vary between 8 and 10. Factor labelling was kept as generic as possible since perfect decomposition is difficult to achieve and factors likely represent a mixture of different sources and processes (e.g. vehicle non-exhaust). Five factors were commonly found at all sites: vehicle exhaust (VEX), vehicle non-exhaust (NEX), secondary nitrate (SNI), sea salt (SEA) and mineral dust (MIN). The biomass burning (BB) source was also found at all sites, except for BCN-UB, where $96 \%$ of homes are heated by natural gas. The secondary sulfate and organics (SSO) factor was separated from the heavy oil combustion (HOC) only 

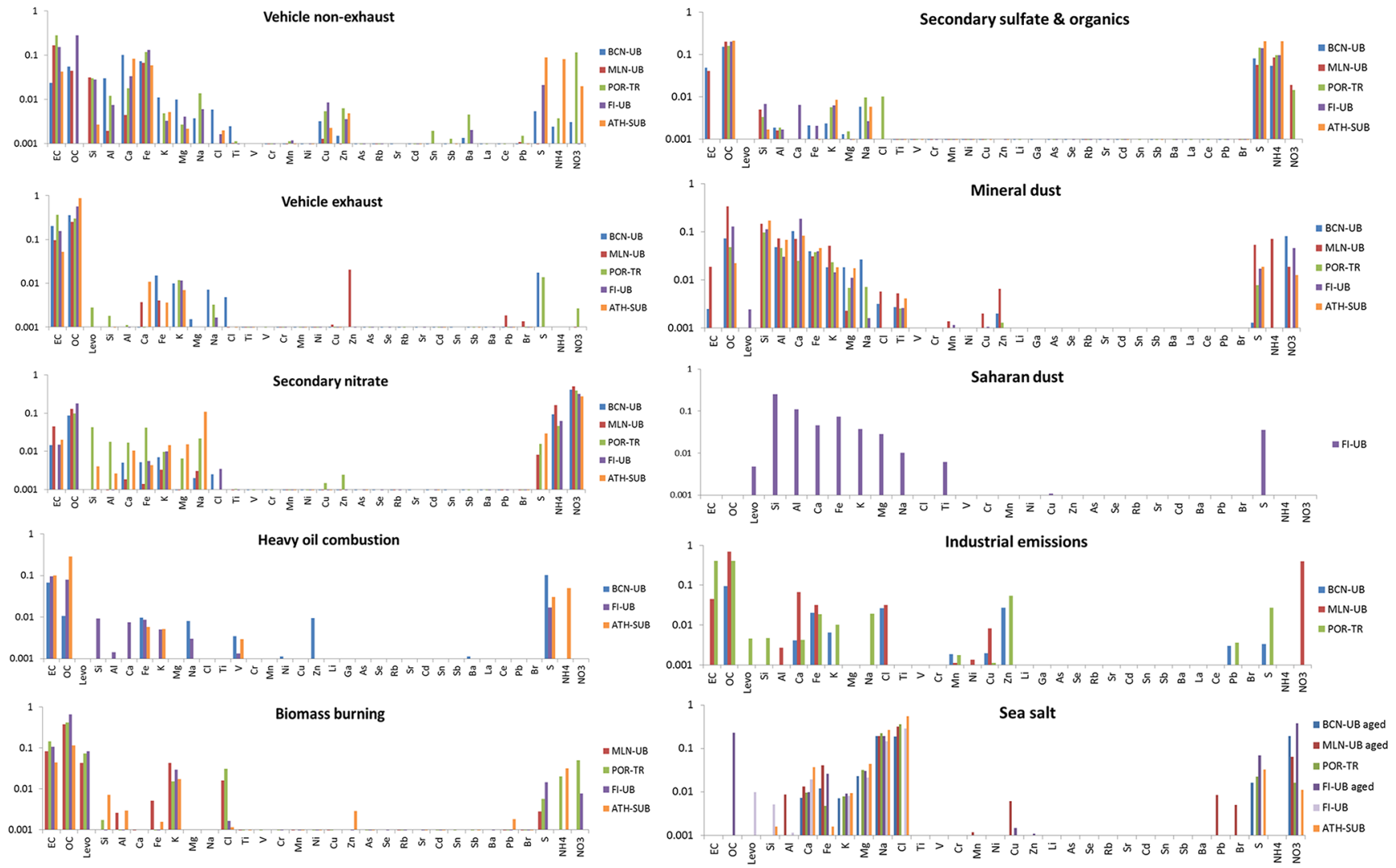

Figure 3. PMF factor profiles $\left(\mu \mathrm{g} \mu \mathrm{g}^{-1}\right)$ for each monitoring site. At MLN-UB and POR-TR, the SSO factor includes heavy oil combustion.

in BCN-UB, FI-UB and ATH-SUB, while in MLN-UB and POR-TR, these two factors were combined in a composite heavy oil and secondary (HOS) factor. In addition, the IND source was identified at BCN-UB, POR-TR and MLN-UB, while possible industrial contributions in FI-UB and ATHSUB would be included in the HOC factor. Finally, in FI-UB, two sea salt factors (aged, with the influence of the refinery located at the coast, and fresh) and two mineral dust factors (local and Saharan dust) were separated.

\section{Traffic sources}

The NEX source generally shows a mixed composition (Fig. 3), including crustal species ( $\mathrm{Fe}, \mathrm{Ca}, \mathrm{Al}$ and $\mathrm{Si}$, among others), carbonaceous compounds (EC generally higher than $\mathrm{OC})$ and trace elements $(\mathrm{Cu}, \mathrm{Zn}, \mathrm{Mn}$ and occasionally $\mathrm{Sn}$, $\mathrm{Sb}$ and $\mathrm{Ba}$ ) from brake wear (see the percentage of species in Tables S2-S6). However, rather dissimilar chemical profiles were found when comparing different cities (Fig. 4). Although the enrichment in $\mathrm{Fe}$ is common to all the cities, the main component of NEX can be either $\mathrm{Ca}$ (in BCN-UB), EC (in POR-TR and MLN-UB), OC (in FI-UB) or S (in AthensSUB). These differences can be due to several factors:
- the proximity to the source: at the traffic site (POR-TR) $28 \%$ of the NEX source is made up by EC, which is probably related to brake particles;

- the climatic conditions: $\mathrm{Ca}$ is higher in drier regions (BCN-UB and ATH-SUB) due to the enhanced resuspension when compared to POR-TR and MLN-UB; and

- the type of materials used for brakes and road pavement (the higher OC in Florence might be due to higher road wear compared to other cities).

Other important differences are the absence of OC in PORTR (again likely due to the dominance of brake wear particles) and in ATH-SUB, and the high abundance of $\mathrm{NO}_{3}^{-}$in POR-TR and $\mathrm{NH}_{4}^{+}$in Athens. Note that some elements are absent in some cities since they were not used for the source apportionment study (see Table 2).

The VEX source at all cities is almost totally composed of carbonaceous aerosol (Fig. 3), with the sum of OC + EC approximately $90-98 \%$ of the mass. The ratio $\mathrm{OC} / \mathrm{EC}$ varies widely among different cities. The lowest $\mathrm{OC} / \mathrm{EC}$ value was found at the traffic site of Porto (POR-TR) due to its proximity to the source and the consequent lower proportion of secondary OC. The value varies between 1.8 and 3.7 at the UB sites, probably linked to the distance from main roads $(\mathrm{BCN}-$ 

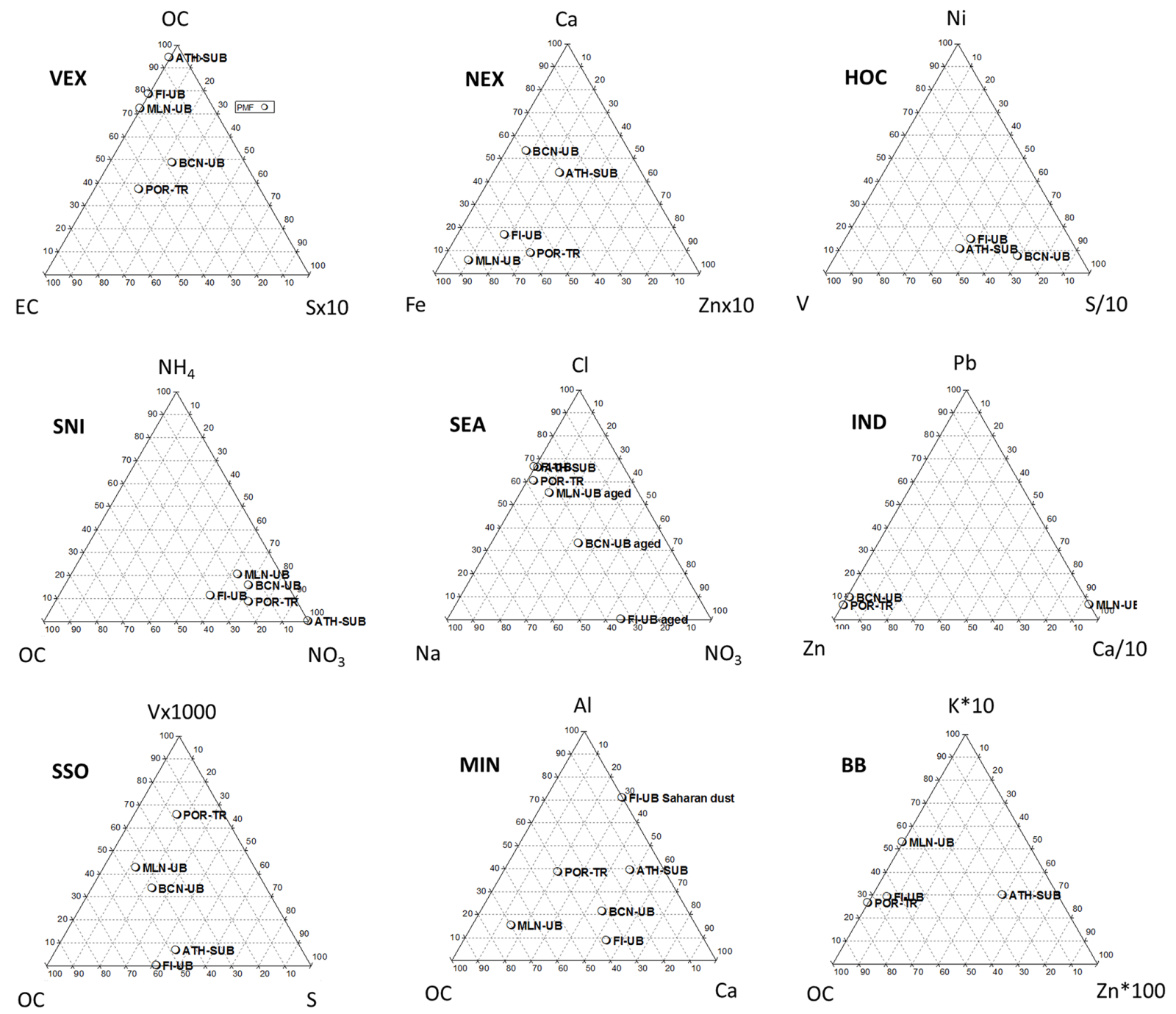

Figure 4. Ternary plots for PMF factor profiles.

UB, MLN-UB and FI-UB). A much higher value (16.4) is observed in ATH-SUB due to the reduced share of diesel vehicles in the local fleet. Besides EC and OC, other components rarely reach $1 \%$ of the mass: $\mathrm{Zn}$ in MLN-UB, $\mathrm{S}$ in BCN-UB and POR-TR due to their relatively higher content in diesel fuel and/or to engine oil anti-wear additive ZDDP (zinc dialkyldithiophosphate). Potassium is present in all unleaded fuels (Spencer et al., 2006), and it is also used as an antifreeze inhibitor and as an additive in some oil types.

The annual mean contributions for VEX and NEX sources and associated errors for each city are shown in Figs. 5 and 6. The error estimates were calculated based on the standard error of the coefficients of a multiple regression between the daily PM concentration (independent variable) and the source contributions (dependent variables). As a result we obtained the symmetric error for each source contribution (Fig. 6).
The sum of VEX and NEX contributions to $\mathrm{PM}_{10}$ varies significantly in absolute terms $\left(3.9-10.8 \mu \mathrm{g} \mathrm{m}^{-3}\right)$, with the maximum found at POR-TR; the fractional contribution to $\mathrm{PM}_{10}$ is within $18-31 \%$. Similarly in $\mathrm{PM}_{2.5}$, absolute annual contributions vary within the range $2.3-9.4 \mu \mathrm{g} \mathrm{m}^{-3}$, but the percentage is quite constant within 14-37\% (Fig. 5). For the total contribution one should add the fraction of secondary nitrate attributable to traffic, but the lack of linearity between emissions and concentrations and the uncertainty in emission inventorying do not allow for a robust estimate. Although the importance of NEX sources has been increasing during the last decade due to the lack of mitigation measures, VEX contribution is still generally higher than NEX. However, the difference (in $\mathrm{PM}_{10}$ ) between the VEX and NEX contribution is not significant at the BCN-UB, FI-UB and ATH-SUB sites, which can be generally interpreted as an equal contribution from the two sub-sources. At the TR site (POR-TR) the VEX contribution is significantly higher (by a factor $>2$ ). 

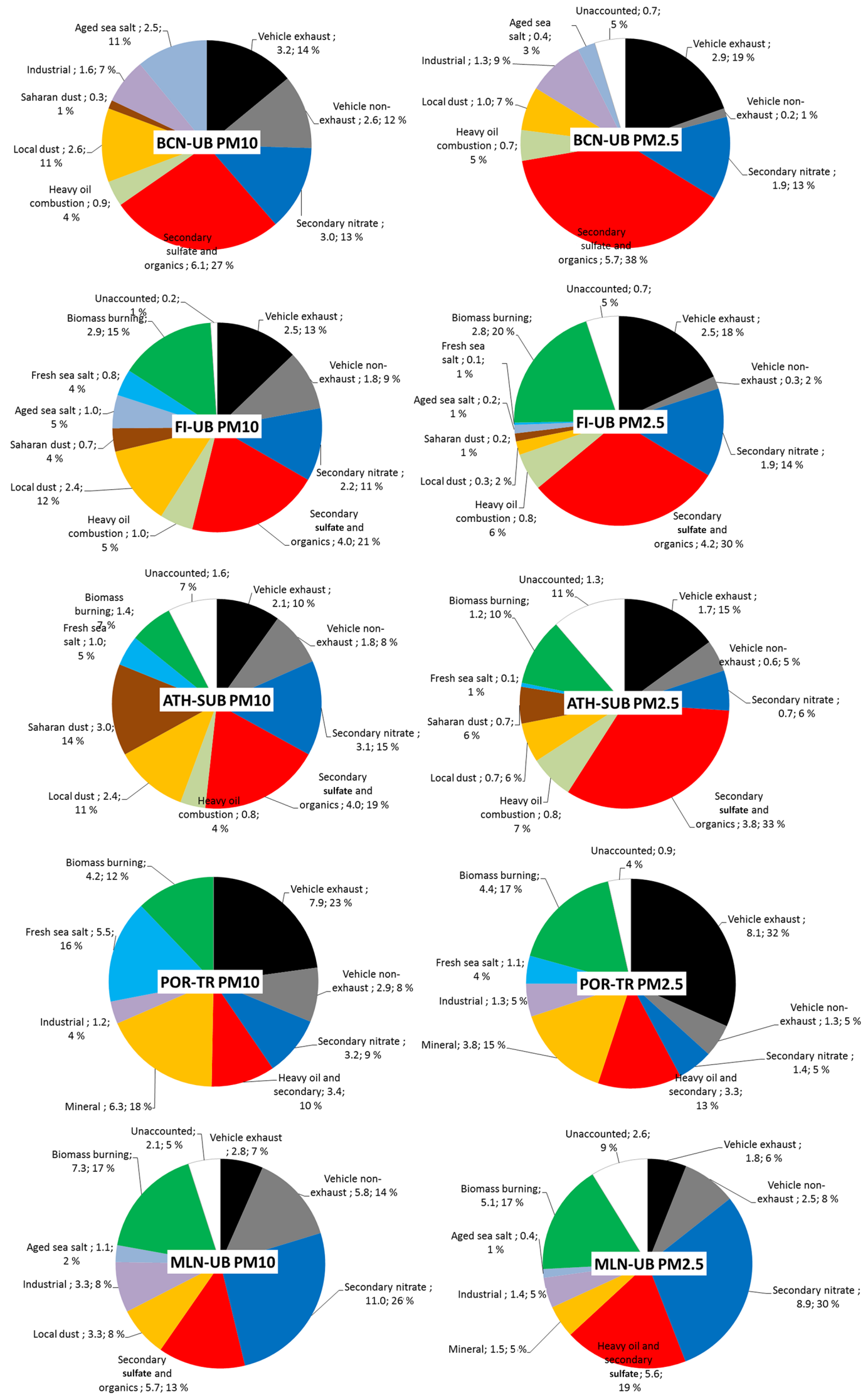

Figure 5. Average contribution (\%) of $\mathrm{PM}_{10}$ and $\mathrm{PM}_{2.5}$ sources for 12 months of study. 


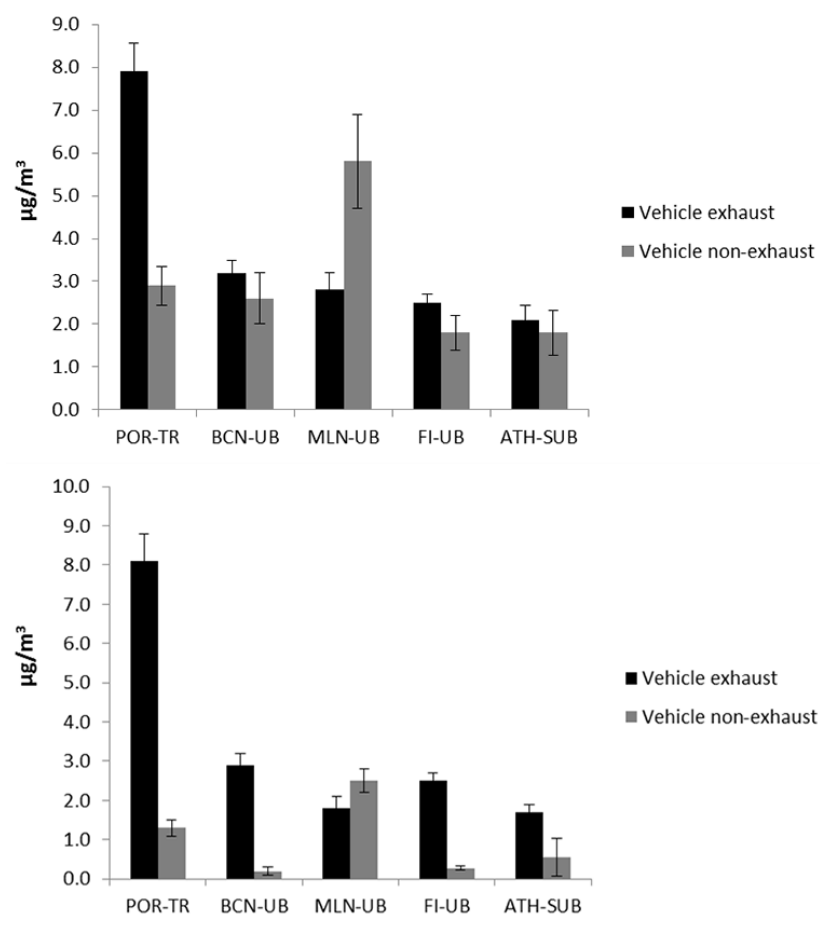

Figure 6. Mean contributions for traffic-related sources at the five AIRUSE cities for $\mathrm{PM}_{10}$ (top panel) and $\mathrm{PM}_{2.5}$ (bottom panel). Error bars are calculated based on the standard error of the coefficients of a multiple regression between the daily PM concentration and the source contributions, and do not include modelling errors.

In $\mathrm{PM}_{2.5}$ the share between VEX and NEX varies considerably, depending on the site (Fig. 6). At POR-TR, BCNUB, FI-UB and ATH-SUB, the emissions from VEX have a higher contribution, but not in MLN-UB. The NEX contribution is significantly lower in $\mathrm{PM}_{2.5}$ due to the coarser size distribution; only in MLN-UB are the VEX and NEX contributions in $\mathrm{PM}_{2.5}$ similar. The daily variation of source contributions at all sites can be seen in Fig. S5.

Individual source contributions were also averaged during days only of exceedances of the $\mathrm{PM}_{10}$ daily limit value $\left(50 \mu \mathrm{g} \mathrm{m}^{-3}\right)$, except in BCN-UB, where this threshold was never reached and $40 \mu \mathrm{g} \mathrm{m}^{-3}$ was used. During exceedance days (or high pollution days), the sum of VEX and NEX contributions changes in $\mathrm{PM}_{10}$ and $\mathrm{PM}_{2.5}$, respectively, from 25 and $21 \%$ to 27 and $22 \%$ in BCN-UB, from 31 and $31 \%$ to 43 and $32 \%$ in FI-UB, from 16 and $15 \%$ to 19 and $13 \%$ in MLN-UB, from 18 and $20 \%$ to 7 and $10 \%$ in ATH-SUB and from 31 and $37 \%$ to 31 and $33 \%$ in POR-TR (Table 3).

\section{Secondary processes}

The secondary nitrate (SNI) factor reproduces nearly the totality of the mass of ammonium nitrate formed from $\mathrm{NO}_{x}$ precursors emitted from traffic, biomass burning and industries. The contribution of road traffic to this factor is unknown. The composition of this factor (Fig. 3) is very simi- lar among the different cities, $\mathrm{NO}_{3}^{-}$being the main component $(28-50 \%)$. Nitrate is usually neutralized by ammonium $(5-16 \%)$ or, in the case of ATH-SUB, by Na $(11 \%)$. Another important component is OC, representing the condensation of semi-volatile organics on the high specific surface area of the ammonium nitrate particles. EC is also present in significant concentrations $(>1 \%)$, although not in the case of POR-TR, where other primary elements can be observed in this profile ( $\mathrm{Si}, \mathrm{Al}, \mathrm{Ca}, \mathrm{Fe}$ and $\mathrm{K})$. As previously explained, the traffic-related share of secondary nitrate is unknown, but at most of the sites it is likely to be very important: as an example, one should consider that the traffic share of the $\mathrm{NO}_{x}$ emission inventory for the study areas is between 30 and $80 \%$. However, the high uncertainty in the emission inventory (mostly for the lack of biomass combustion emissions) does not allow drawing of quantitative estimates. The secondary nitrate annual average contributions to $\mathrm{PM}_{10}$ range from $2.2 \mu \mathrm{g} \mathrm{m}^{-3}$ in FI-UB, $3.0-3.2 \mu \mathrm{g} \mathrm{m}^{-3}$ in PORTR, BCN-UB and ATH-SUB, to $11.0 \mu \mathrm{g} \mathrm{m}^{-3}$ in MLN-UB. For $\mathrm{PM}_{2.5}$ the annual contributions are in the range between $0.7 \mu \mathrm{g} \mathrm{m}^{-3}$ (ATH-SUB) and $8.9 \mu \mathrm{g} \mathrm{m}^{-3}$ in MLN-UB. As already mentioned, these high nitrate levels in the Po Valley are due to several factors: (i) a large urban and industrial agglomeration and associated road traffic; (ii) an intensive use of biomass burning in the basin; (iii) high $\mathrm{NH}_{3}$ levels, emitted from agricultural and animal husbandry activities; and (iv) the peculiar meteorology favouring frequent and marked thermal inversions.

Factor SSO was found at all cities with a rather constant composition, revealing a mainly regional origin of these aerosols across the Mediterranean (Fig. 3). The main components are $\mathrm{S}, \mathrm{NH}_{4}^{+}$and OC. EC can also be found at 4 $5 \%$ concentration in BCN-UB and MLN-UB, indicating a mixing with other (primary) sources. At two sites (POR-TR and MLN-UB), this factor was combined with the heavy oil combustion, thus adding $\mathrm{NO}_{3}^{-}, \mathrm{V}$ and $\mathrm{Ni}$, which in the other cities (BCN-UB, FI-UB and ATH-SUB) appears as an independent source. Other elements that can appear in this source are $\mathrm{Si}, \mathrm{Na}$ and $\mathrm{K}$, although in concentrations below $1 \%$. SSO aerosols are at all sites in the fine mode (ratio $\mathrm{PM}_{2.5} / \mathrm{PM}_{10}$ close to 1 ), but the variability of contributions across the Mediterranean does not show the same pattern observed for the concentrations of sulfate. The contributions were progressively increasing from POR-TR $\left(3.3 \mu \mathrm{g} \mathrm{m}^{-3}\right.$ in $\left.\mathrm{PM}_{2.5}\right)$, ATH-SUB $\left(3.8 \mu \mathrm{g} \mathrm{m}^{-3}\right)$, and FI-UB $\left(4.2 \mu \mathrm{g} \mathrm{m}^{-3}\right)$ to MLNUB and BCN-UB $\left(5.7 \mu \mathrm{g} \mathrm{m}^{-3}\right)$ (Fig. 5). The reason for this higher contribution might be related to the inclusion of some local sources, as suggested by the presence of EC primary combustion particles only at these two sites. The seasonal trend is clear with maxima in the warmer months, probably due to the enhanced photochemical activity; this is less clear in MLN-UB, where high concentrations in autumn and winter may be due to aqueous phase formation in the fogs which occur frequently at this time of year (Fig. S5). POR-TR registered the highest daily peaks, when the site is under the 
Table 3. Average contribution (\%) of $\mathrm{PM}_{10}$ and $\mathrm{PM}_{2.5}$ sources during high pollution days $\left(\mathrm{PM}_{10}>50 \mu \mathrm{g} \mathrm{m}^{-3}\right.$ and $>40 \mu \mathrm{g} \mathrm{m}{ }^{-3}$ in $\mathrm{BCN}-$ UB).

\begin{tabular}{|c|c|c|c|c|c|c|c|c|c|c|}
\hline & \multicolumn{2}{|c|}{ BCN-UB } & \multicolumn{2}{|c|}{ FI-UB } & \multicolumn{2}{|c|}{ ATH-SUB } & \multicolumn{2}{|c|}{ POR-TR } & \multicolumn{2}{|c|}{ MLN-UB } \\
\hline & $\mathrm{PM}_{10}$ & $\mathrm{PM}_{2.5}$ & $\mathrm{PM}_{10}$ & $\mathrm{PM}_{2.5}$ & $\mathrm{PM}_{10}$ & $\mathrm{PM}_{2.5}$ & $\mathrm{PM}_{10}$ & $\mathrm{PM}_{2.5}$ & $\mathrm{PM}_{10}$ & $\mathrm{PM}_{2.5}$ \\
\hline Aged sea salt & 2 & 1 & $<1$ & $<1$ & & & 3 & $<1$ & 2 & 1 \\
\hline Saharan dust & $<1$ & $<1$ & $<1$ & $<1$ & 52 & 45 & $<1$ & $<1$ & $<1$ & $<1$ \\
\hline Local dust & 4 & 2 & $<1$ & $<1$ & 1 & 2 & 27 & 22 & 3 & 2 \\
\hline Sec. sulfate and organics & 19 & 22 & 6 & 6 & 2 & 5 & $5^{*}$ & $2^{*}$ & $9^{*}$ & $11^{*}$ \\
\hline Vehicle non-exhaust & 14 & 2 & 9 & 1 & 3 & 1 & 6 & 3 & 14 & 8 \\
\hline Vehicle exhaust & 13 & 20 & 5 & 5 & 4 & 9 & 25 & 30 & 5 & 5 \\
\hline Heavy oil combustion & 4 & 6 & 3 & 3 & 3 & 10 & & & & \\
\hline Industrial & 17 & 18 & & & $<1$ & $<1$ & 2 & 1 & 4 & 3 \\
\hline Secondary nitrate & 27 & 29 & 36 & 32 & 3 & 4 & 7 & 3 & 28 & 34 \\
\hline Fresh sea salt & & & $<1$ & $<1$ & 7 & 1 & & & & \\
\hline Biomass burning & & & 30 & 33 & 1 & 2 & 25 & 33 & 35 & 26 \\
\hline Unaccounted & & & 8 & 20 & 24 & 21 & & 5 & & 10 \\
\hline
\end{tabular}

* includes heavy oil combustion.

influence of NW winds, probably due to the emissions from the Porto Refinery, a plant carrying out crude oil industrial processing for the petrochemical industry.

During exceedance days (or high pollution days), the SSO contribution in $\mathrm{PM}_{10}-\mathrm{PM}_{2.5}$ always decreases from 27-38 to $19-22 \%$ in BCN-UB, from $10-13$ to $5-2 \%$ in POR-TR, from $21-30$ to $6-6 \%$ in FI-UB, from $13-19$ to $9-11 \%$ in MLN-UB, and from 19-32 to 2-5\% in ATH-SUB (Table 3).

\section{Marine aerosols}

Depending on the geography of each site, sea salt can reach the receptor in a "fresh" or "aged" form, or both. The main chemical difference is the absence of chlorine in the aged sea salt coupled with the presence of the nitrates, which means that sodium is in the form of sodium nitrate. Fresh sea salt was identified at POR-TR, FI-UB and ATH-SUB, while aged sea salt was found at MLN-UB, FI-UB and BCN-UB. As shown in Fig. 3, the mass fraction of nitrate $\left(\mu \mathrm{g} \mu \mathrm{g}^{-1}\right)$ is considerably higher in the aged profiles, by 1 order of magnitude when compared to the fresh profile. In FI-UB, where both fresh and aged factors were found, nitrate is absent in the fresh sea salt and chlorine is absent in the aged factor, which also shows a particularly high level of OC, indicating the mixing of the aged sea salt with anthropogenic plumes, likely due to the refinery emissions at the coast of Livorno. In all factors the absence of ammonium indicates clearly the neutralization of nitrate by sodium. Mean contributions of sea salt (Fig. 5) in $\mathrm{PM}_{10}$ were revealed to be generally higher (by $25 \%$ ) than what was found with the chemical speciation (2.5 vs. $1.5 \mu \mathrm{g} \mathrm{m}^{-3}$ in BCN-UB, 5.5 vs. $4.4 \mu \mathrm{g} \mathrm{m}^{-3}$ in PORTR, 1.8 vs. $0.6 \mu \mathrm{g} \mathrm{m}^{-3}$ in FI-UB, 1.1 vs. $0.7 \mu \mathrm{g} \mathrm{m}^{-3}$ in MLN$\mathrm{UB}$, and $1.0 \mathrm{vs} .1 .6 \mu \mathrm{g} \mathrm{m}^{-3}$ in ATH-SUB) due to the involvement of coarse nitrate and water. In $\mathrm{PM}_{2.5}$ the PMF contribution matches with the chemical data (slope $=1, r^{2}=0.95$ ).
Consequently, the comparison of PMF contributions reflects the same conclusions drawn in the PM speciation section, with lower levels of sea salt at the inland Italian cities (FI and MLN) and higher at the Mediterranean coastal sites, with the highest contribution observed at the Atlantic site (POR). Daily source contributions can be seen in Fig. S5. During exceedance days (or high pollution days), the sea salt contribution in $\mathrm{PM}_{10}-\mathrm{PM}_{2.5}$ generally decreases from $11-3$ to $2-1 \%$ in BCN-UB, from $16-4$ to $3-0 \%$ in POR-TR, from 9-2 to $0-1 \%$ in FI-UB, or does not change in MLN-UB and ATH-SUB (Table 3).

\section{Mineral sources}

Saharan dust was separated from local dust only at FI-UB, BCN-UB and ATH-SUB (by means of PMF in FI and by the percentile method for BCN and ATH). In MLN-UB and POR-TR the contribution of Saharan dust was estimated as negligible. The chemical profile of Saharan dust (as estimated in FI-UB by PMF) shows a composition very close to the average of the earth's crust, with enrichment factors $(\mathrm{EF})$ calculated with respect to $\mathrm{Al}$ using the average continental crust composition reported by Mason (1966) and Rahn (1976) that are all close to 1: $0.99(\mathrm{Mg}), 0.83(\mathrm{Si})$, $1.08(\mathrm{~K}), 0.92(\mathrm{Ca}), 1.0(\mathrm{Ti})$ and $1.1(\mathrm{Fe})$ (Fig. 3). The annual mean Saharan dust contribution during AIRUSE sampling days was estimated as $0.3 \mu \mathrm{g} \mathrm{m}^{-3}(1 \%)$ in BCN-UB, $0.7 \mu \mathrm{g} \mathrm{m}^{-3}(4 \%)$ in FI-UB, and $3.0 \mu \mathrm{g} \mathrm{m}^{-3}(14 \%)$ in ATHSUB (Fig. 5). This large difference is due to the southern location of Athens and the severity of some Saharan dust episodes in the eastern part of the basin with a higher frequency than average during the period of this study. As mentioned by previous studies, Saharan dust transport occurs in different seasons on the western and eastern sides of the Mediterranean (Querol et al., 2009). Saharan dust 
inputs on the western side of the Mediterranean are considerably higher between May and October, and in March, when compared to the rest of the year. By contrast, such inputs are clearly higher between November and May in the eastern part of the Mediterranean. An intermediate outcome is observed for central locations in the Mediterranean, where only slightly higher summer contributions are detected. For $\mathrm{PM}_{2.5}$ the SAH contribution was estimated only at FI-UB $\left(0.2 \mu \mathrm{g} \mathrm{m}^{-3}\right)$ and ATH-SUB $\left(0.7 \mu \mathrm{g} \mathrm{m}^{-3}\right)$, with a $\mathrm{PM}_{2.5} / \mathrm{PM}_{10}$ ratio equal to 0.2 in both cases. Concerning PM exceedances, the relative burden of Saharan dust increases during exceedance days only in ATH-SUB, where it is on average the main source of $\mathrm{PM}_{10}(52 \%)$ and $\mathrm{PM}_{2.5}(45 \%)$ when the daily limit value of $50 \mathrm{\mu g} \mathrm{m}^{-3}$ is exceeded. No contributions from SAH were found in FI-UB and BCN-UB during days with $\mathrm{PM}_{10}$ above 50 and $40 \mu \mathrm{g} \mathrm{m}^{-3}$, respectively.

Besides the long-range transported mineral dust from the Sahara, a significant part of mineral dust was found to be locally emitted in all cities (local dust, LDU). The ratio $\mathrm{SAH} / \mathrm{LDU}$ is usually very low, $<0.1$ in POR-TR and MLN$\mathrm{UB}, 0.1$ in BCN-UB and 0.3 in FI-UB, indicating that at these sites Saharan dust is $0-23 \%$ of measured mineral dust, with the rest emitted by human activities or of local origin. Only in ATH-SUB was the SAH contribution higher (ratio $\mathrm{SAH} / \mathrm{LDU}=1.4$ ) than the local dust due both to the geographical position of Athens and the suburban location of the measurement site (i.e. a lower anthropogenic contribution than at UB sites). The chemical profile of LDU is the one shown in Fig. 3 (the MIN profile is used). Although the major components are similar at all sites $(\mathrm{Si}, \mathrm{Al}, \mathrm{Ca}, \mathrm{Fe}, \mathrm{OC}$ and $\mathrm{K}$ ), some differences can be observed. The highest ratio $\mathrm{Ca} / \mathrm{Al}$ is found in FI-UB (6.3) due to the clear PMF separation from the $\mathrm{SAH}$ contribution (ratio $\mathrm{Ca} / \mathrm{Al}=0.4$, similar to the earth's crust). The other cities show $\mathrm{Ca} / \mathrm{Al}$ ratios in the mineral dust factors varying from 0.5 (POR-TR) to 2.2 (BCN-UB), which are influenced by the SAH contribution as well as the local geology and share of Ca-rich local emissions. The ratio $\mathrm{Si} / \mathrm{Al}$ varies between 2.0 and 3.8. The ratio $\mathrm{OC} / \mathrm{Ca}$ is generally well above the stoichiometric $\mathrm{CC} / \mathrm{Ca}$ ratio in calcite $(0.3)$, revealing additional sources of organic carbon such as biogenic OC and/or road dust, mostly in MLN-UB, where the complex atmospheric dynamics impede the separation of sources. Other common components of LDU are $\mathrm{NO}_{3}^{-}$(except in POR-TR), S likely from gypsum, $\mathrm{Cu}, \mathrm{Zn}$ and $\mathrm{Ba}$, suggesting possible interference from road dust. LDU contributions to $\mathrm{PM}_{10}$ range between 8 and $12 \%$ at SUB and UB sites (2.4-3.3 $\left.\mu \mathrm{g} \mathrm{m}^{-3}\right)$ and increase to $6.3 \mu \mathrm{g} \mathrm{m}^{-3}(18 \%)$ at the TR site, revealing a contribution from road dust resuspension. In $\mathrm{PM}_{2.5}$ the SUB-UB range was $0.3-1.5 \mu \mathrm{g} \mathrm{m}^{-3}(2-7 \%)$ and $3.8 \mu \mathrm{g} \mathrm{m}^{-3}(15 \%)$ at the TR site. The relative contribution (\%) does not increase during exceedance days, with the exception of POR-TR, where it rises to 28 and $20 \%$ for $\mathrm{PM}_{10}$ and $\mathrm{PM}_{2.5}$, respectively. The daily variation of LDU contributions shows generally higher values from spring to autumn at all cities (Fig. S5). Above the background contributions, sporadic peaks are also found, mostly at POR-TR, probably related to road dust emissions not completely included in the NEX factor.

\section{Heavy oil combustion}

As already mentioned, the contribution of heavy oil combustion was separated only at the cities nearest to the Mediterranean shipping routes (BCN, FI and ATH) in spite of the fact that $\mathrm{V}$ and $\mathrm{Ni}$ concentrations in POR-TR were twice as high as in FI-UB. In POR-TR and MLN-UB, the HOC source is mixed with the SSO in the combined source HOS. HOC particles are commonly composed of EC, OC and S, explaining the high variance of $\mathrm{V}$ and $\mathrm{Ni}$. The difference between AIRUSE sites concerns only specific trace elements such as $\mathrm{Zn}, \mathrm{Sn}$ and $\mathrm{Ba}$ (in BCN-UB), Ba and Se (in FI-UB), or $\mathrm{Sr}$ and $\mathrm{Sb}$ (in ATH-SUB), although only a small amount of variance of these elements is explained by HOC (Tables S2S6). The annual contribution of $\mathrm{HOC}$ is practically the same in BCN-UB, FI-UB and ATH-SUB $\left(0.8-1.0 \mu \mathrm{g} \mathrm{m}^{-3}\right.$ in PM 10 and $0.7-0.8 \mu \mathrm{g} \mathrm{m}^{-3}$ in $\mathrm{PM}_{2.5}$ ). The contribution in POR-TR and MLN-UB could not be separated from the composite HOS. The daily variation of HOC contributions, as estimated by PMF, is shown in Fig. S5. In FI-UB and BCN-UB higher contributions are observed in summer due to the higher air circulation, which favours their transport and distribution across the regional area, while in ATH-SUB no clear seasonal trend is observed for HOC probably because of the variety of the sources that may contribute to this factor (residential heating and shipping). During exceedance days (or high pollution days), the HOC contribution in $\mathrm{PM}_{10}-\mathrm{PM}_{2.5}$ does not change significantly.

\section{Industrial emissions}

The impact of industrial emissions was identified in only three cities: BCN-UB, POR-TR and MLN-UB. Florence and Athens are in fact the less industrialized cities among the AIRUSE consortium. In the three industrialized cities, $\mathrm{OC}$ and $\mathrm{Fe}$ are commonly present as the main components (Fig. 3). Besides OC and Fe, in BCN-UB and POR-TR the presence of $\mathrm{Zn}, \mathrm{Pb}, \mathrm{S}, \mathrm{Cu}, \mathrm{Cd}, \mathrm{Sb}$ and $\mathrm{Mn}$ indicates hightemperature metal processing, pointing to the smelters located south-west of BCN-UB and east of POR-TR. In MLNUB the industrial source presents a different chemical profile with $\mathrm{NO}_{3}^{-}, \mathrm{EC}, \mathrm{Ca}$ and $\mathrm{Cl}$ as the main components (together with $\mathrm{OC}$ and $\mathrm{Fe}$ ) and a high variance of $\mathrm{Cr}, \mathrm{Ni}, \mathrm{Cu}$ and $\mathrm{Mn}$ explained, suggesting a more mixed origin, including metallurgy and construction activities (Tables S2-S6). The impact of industrial emissions upon $\mathrm{PM}_{10}$ and $\mathrm{PM}_{2.5}$ is similarly low at MLN, POR and BCN, ranging between 1.2 and $3.3 \mu \mathrm{g} \mathrm{m}^{-3}$ as annual means and with a $\mathrm{PM}_{2.5} / \mathrm{PM}_{10}$ ratio close to 1 . No typical seasonal trend is observable at any site (Fig. S5). The contribution was rather constant throughout the year (around $1 \mu \mathrm{g} \mathrm{m}^{-3}$ daily) in MLN-UB and BCN-UB, while elevated 
peaks (up to $13 \mu \mathrm{g} \mathrm{m}^{-3}$ as a daily mean) are registered in POR-TR, mostly in the warmer months. During exceedance days (or high pollution days), the IND contribution in $\mathrm{PM}_{10}$ $\mathrm{PM}_{2.5}$ slightly increases from $11-12 \%$ to $17-19 \%$ in $\mathrm{BCN}-$ UB, and decreases from $4-5$ to $2-1 \%$ in POR-TR and from 9-5 to $4-3 \%$ in MLN-UB (Table 3).

\section{Biomass burning}

As previously shown, concentrations of levoglucosan varied by over 1 order of magnitude among the AIRUSE cities, indicating very contrasting scenarios across the Mediterranean for emissions from biomass burning. Similarly, the PMF identified a biomass burning source only in four of the five cities due to the low levels of levoglucosan in BCN-UB (20 $\mathrm{ng} \mathrm{m}^{-3}$ as annual mean). In all other cities, levoglucosan is the main tracer in the chemical profile of the biomass burning source identified by PMF (except in ATH-SUB, where levoglucosan was not used as input species for PMF due to the high S / N ratio). Levoglucosan represents 4-8\% of PM mass in the biomass burning factor profile; $\mathrm{OC}$ and $\mathrm{EC}$ are the major components in the BB profile (12-65 and 4-14\%, respectively). In spite of these quite large ranges, the $\mathrm{OC} / \mathrm{EC}$ ratio can be used as a more robust diagnostic of $\mathrm{BB}$ composition. The OC / EC ratio in BB aerosols varies from 2.6 (ATHSUB), 2.9 (POR-TR), 4.6 (MLN-UB) to 6.1 (FI-UB), which may be explained by a higher proportion of secondary organic aerosols in MLN-UB and FI-UB or by different wood types and combustion appliances. Also, K (probably the soluble fraction) tracks BB aerosols, representing $2-4 \%$ of the mass. Other components can be observed, although more sporadically, such as $\mathrm{Cl}, \mathrm{S}, \mathrm{Zn}, \mathrm{Pb}, \mathrm{NH}_{4}^{+}$and $\mathrm{NO}_{3}^{-}$(Fig. 3 and Tables S2-S6). BB contributions reproduce quite well the gradients found for levoglucosan among the AIRUSE cities. Although levoglucosan has been detected in some samples from $\mathrm{BCN}$, biomass burning could not be assigned as a significant contributor to PM. In the other cities, an annual mean of $1.2-1.4 \mathrm{gm}^{-3}(7-10 \%)$ is estimated in ATH-SUB, 2.9$2.8 \mu \mathrm{g} \mathrm{m}^{-3}(15-20 \%)$ in FI-UB, $4.2-4.4 \mu \mathrm{g} \mathrm{m}^{-3}(12-17 \%)$ in POR-TR, and up to 7.3-5.1 $\mu \mathrm{g} \mathrm{m}^{-3}(17 \%)$ in MLN-UB. Therefore, this reveals quite a contrasting impact of BB emissions across the Mediterranean, depending on the type of fuel and combustion device used in each region for residential heating. Differently from other cities, Barcelona is well supplied with natural gas for residential heating; Florence is also well supplied with natural gas, but in the suburbs on the hill there are commonly chimneys. Even in Milan the use of natural gas for heating is very extensive; however, also due to the current economic crisis, many citizens are equipped with small pellet stoves. In ATH the BB source is also associated with tracers of waste combustion, such as As, Cd, $\mathrm{Sb}$ and $\mathrm{Pb}$, with explained variance ranging between 12 and $72 \%$, as citizens of Athens have turned to alternative heating fuels, such as wood, due to the economic crisis and the increased prices of diesel oil, which has been the regular means of residential heating in Greece. In many cases, treated wood or even combustible wastes are now used as fuel. As previously shown for the traffic source, another factor identified by PMF was secondary nitrate (SNI). Although in urban environments nitrate mainly arises from $\mathrm{NO}_{x}$ from traffic, a substantial fraction can also be derived from biomass burning emissions. Therefore for each city, the corresponding share of $\mathrm{NO}_{x}$ due to biomass burning can also be applied to SNI. Based on this approach, percentages of 16 and 13 were adopted in POR-TR and MLN-UB, respectively, to account for SNI from biomass burning. In FI-UB, on the basis of the emission inventory, about $10 \%$ of $\mathrm{NO}_{x}$ emissions are due to domestic heating, with only $2 \%$ attributable to stoves and chimneys (http://servizi2.regione.toscana.it/aria/); it is however suspected that these data underestimate the contribution of domestic heating $\mathrm{BB}$ to $\mathrm{NO}_{x}$. Thus, in POR-TR, the total contribution from BB was estimated to be $4.7 \mu \mathrm{g} \mathrm{m}^{-3}$ (13\% of $\mathrm{PM}_{10}$ ) and $4.6 \mu \mathrm{g} \mathrm{m}^{-3}$ (18\% of $\mathrm{PM}_{2.5}$ ). In MLN-UB, the total contribution from BB represented $8.7 \mu \mathrm{g} \mathrm{m}^{-3}$ in $\mathrm{PM}_{10}$ $(23 \%)$ and $6.3 \mu \mathrm{g} \mathrm{m}^{-3}$ in $\mathrm{PM}_{2.5}(21 \%)$.

The impact of BB emissions is especially high in the winter months (Fig. S5), due to the generalized use of wood for residential heating (Gonçalves et al., 2012). The contribution of BB to PM in POR-TR was also higher in September. Several wildfires were registered in the Porto district in this particularly hot and dry month. In MLN-UB the stagnant conditions and reduced boundary layer height induced by the typical meteorology of the Po Valley also enhance BB contributions during winter months. The relative contribution from biomass burning to $\mathrm{PM}_{10}$ and $\mathrm{PM}_{2.5}$ generally increases on exceedance days in POR-TR, MLN-UB and FIUB. The percentages increase in fact from 23-21 to 35-26\% in MLN-UB, from 13-18 to 25-36\% (POR-TR), and from 15-20 to 30-32\% (FI-UB). Conversely, in ATH-SUB, during exceedance days, the contribution from BB is substantially reduced (from $7-10$ to $1-2 \%$, Table 3 ). This is again due to exceedances in Athens being caused by African dust intrusions and the relative suppression of other source contributions during exceedance days.

Recent research attention has been focused on the importance of other sources/processes contributing to the nonfossil OC in urban ambient air, namely food cooking (Crippa et al., 2013; Allan et al., 2010; Mohr et al., 2012) and enhanced biogenic secondary aerosols (Hoyle et al., 2011; Kroll et al., 2006). The quantification of these two sources/processes requires the use of a combination of measurement techniques: Aerosol Mass Spectrometer (AMS) and offline radiocarbon analysis on PM filters, which could not be performed within AIRUSE. For example, in summer in Barcelona, cooking was estimated to be responsible for $17 \%$ of organic aerosols (OA being $60 \%$ of PM1) (Minguillón et al., 2015), while in Athens, COA was not found as a separate source, but mixed with the traffic-related factor, contributing $17 \%$ of OA (Kostenidou et al., 2015). The influence of road traffic emissions such as $\mathrm{NO}_{x}$ on the forma- 
tion of biogenic secondary aerosols (Hoyle et al., 2011) has been observed in Barcelona, where an increase in non-fossil secondary organic aerosol was registered when comparing a period with low traffic emissions with a period with high traffic emissions, supported by the increase in individual organic compounds such as poly-acids (malic acid, 3-hydroglutaric acid, MBTCA and 2-methylglyceric acid) (Minguillón et al., 2015).

\section{Conclusions}

Based on the simultaneous chemical characterization of $\mathrm{PM}_{10}$ and $\mathrm{PM}_{2.5}$ samples collected every third day across 12 months at five southern European cities, important differences were observed. Thus, in FI-UB, MLN-UB and POR$\mathrm{TR}, \mathrm{OM}+\mathrm{EC}$ was the main $\mathrm{PM}_{10}$ constituent, accounting for 57,45 and $37 \%$ of the $\mathrm{PM}_{10}$ load and 69,45 and $48 \%$ of the $\mathrm{PM}_{2.5}$. However, at BCN-UB and ATH-SUB these PM components were still dominant, but made up only 27 and $36 \%$ of $\mathrm{PM}_{10}$ and 30 and $45 \%$ of $\mathrm{PM}_{2.5}$.

The PM fraction accounted for by secondary inorganic aerosols (sulfate, nitrate and ammonium) also showed significant variations with a load of $18-20 \%$ of $\mathrm{PM}_{10}$ for FIUB and BCN-UB, $30 \%$ for ATH-SUB and $35 \%$ in MLN$\mathrm{UB}$, and $21-22 \%$ of $\mathrm{PM}_{2.5}$ for FI-UB and BCN-UB, $33 \%$ in MLN-UB and $37 \%$ for ATH-SUB. For the POR-TR site the SIA percentage was reduced due to the increase in contributions from OM + EC (mostly from exhaust emissions) and mineral dust (mostly from road dust), and made up $15 \%$ of $\mathrm{PM}_{10}$ and $\mathrm{PM}_{2.5}$.

Mineral dust was one of the main $\mathrm{PM}_{10}$ components at all sites, ranging from 10 (MLN-UB) to $21 \%$ (ATH-SUB) of the $\mathrm{PM}_{10}$ load. In $\mathrm{PM}_{2.5}$, as expected from the coarser mode of occurrence of mineral dust, the contribution was reduced down to 4 (FI)-10\% (ATH) in all cases.

The sea salt contribution reached the maximum at the Atlantic site, $13 \%$ of $\mathrm{PM}_{10}$ and $5 \%$ of $\mathrm{PM}_{2.5}$ in POR, followed by the other two Mediterranean coastal sites, BCN and ATH (7 and $8 \%$ of $\mathrm{PM}_{10}$ and 3 and $2 \%$ of $\mathrm{PM}_{2.5}$ ); the minimum sea salt contributions were recorded in the inland Italian cities, MLN and FI (2-3\% of $\mathrm{PM}_{10}$ and $1 \%$ of $\mathrm{PM}_{2.5}$ ).

The sum of vehicle exhaust and vehicle non-exhaust emissions is unequivocally the most important source of $\mathrm{PM}_{10}$ (18-31\% at all sites, except in MLN-UB, where SNI and SSO dominate the mass), while for $\mathrm{PM}_{2.5}$ it is clearly the largest source of POR-TR (37\%) and the second one at BCN-UB, FI-UB and ATH-SUB after secondary sulfate and organics (which likely receives significant transboundary contributions). In $\mathrm{PM}_{2.5}$ MLN-UB secondary nitrate is the main contributor, although it does not identify one specific source.

Another important "source" of $\mathrm{PM}_{10}(19-27 \%)$ is secondary sulfate and organics at BCN-UB, FI-UB and ATHSUB, while this only represents $13 \%$ of $\mathrm{PM}_{10}$ in MLN-
$\mathrm{UB}$ and $10 \%$ of $\mathrm{PM}_{10}$ in POR-TR. The relative importance of secondary sulfate and organics is higher in $\mathrm{PM}_{2.5}$ (19-38\% at the SUB and UB sites and $13 \%$ in POR-TR). The contributions (in $\mathrm{PM}_{2.5}$ ) progressively increase from POR-TR $\left(3.3 \mu \mathrm{g} \mathrm{m}^{-3}\right)$, ATH-SUB $\left(3.8 \mu \mathrm{g} \mathrm{m}^{-3}\right)$, and FI-UB $\left(4.2 \mu \mathrm{g} \mathrm{m}^{-3}\right)$ to MLN-UB and BCN-UB $\left(5.6-5.7 \mu \mathrm{g} \mathrm{m}^{-3}\right)$.

Another important source of $\mathrm{PM}_{10}$ is biomass burning (13\% in POR-TR, $15 \%$ in FI-UB, and $23 \%$ in MLN-UB), although it is only $7 \%$ in ATH-SUB and negligible in BCNUB. In $\mathrm{PM}_{2.5}, \mathrm{BB}$ is the second most important source in MLN-UB $(21 \%)$ and in POR-TR $(18 \%)$, the third in FI-UB (20\%) and ATH-SUB (10\%), but again negligible $(<2 \%)$ in BCN-UB. This large discrepancy among cities is mostly due to the degree of penetration of wood (and its derivatives) as fuel for residential heating. In Barcelona natural gas is very well supplied across the city and used as fuel in $96 \%$ of homes, while, in other cities, PM levels increase on an annual basis by $1-6 \mu \mathrm{g} \mathrm{m}^{-3}$ due to this source.

Other significant anthropogenic sources are the following.

- Local dust, 8-12\% of $\mathrm{PM}_{10}$ at the SUB and UB sites and $18 \%$ at the TR site, revealing a contribution from road dust resuspension. In $\mathrm{PM}_{2.5}$, percentages decrease to $2-7 \%$ at the SUB-UB sites and $15 \%$ at the TR site.

- Industry, mainly metallurgy, contributing 4-8\% of $\mathrm{PM}_{10}$ (5-9\% in $\mathrm{PM}_{2.5}$ ), but only at BCN-UB, POR-TR and MLN-UB. No clear impact of industrial emissions was found in FI-UB and ATH-SUB.

- Natural contributions consist of sea salt (16\% of $\mathrm{PM}_{10}$ in POR-TR but only $2-11 \%$ in the other cities) and Saharan dust (14\% in ATH-SUB but less than $4 \%$ in the other cities).

- Other sources of non-fossil OC, such as food cooking and the formation of enhanced biogenic secondary organic aerosol, could not be separated due to the lack of specific techniques.

During high pollution days, the largest specific sources (i.e. excluding $\mathrm{SSO}$ and $\mathrm{SNI}$ ) of $\mathrm{PM}_{10}$ and $\mathrm{PM}_{2.5}$ are VEX + NEX in BCN-UB (27-22\%) and POR-TR (31$33 \%)$, BB in FI-UB (30-33\%) and MLN-UB (35-26\%) and Saharan dust in ATH-SUB (52-45\%). During those days, there are also quite important industrial contributions in BCN-UB (17-18\%) and local dust in POR-TR (28-20\%). The Supplement related to this article is available online
at doi:10.5194/acp-16-3289-2016-supplement. 
Acknowledgements. This work was funded by the AIRUSE LIFE+ (ENV/ES/584) EU project. Fulvio Amato is a beneficiary of the Juan de la Cierva postdoctoral grant (JCI-2012-13473) from the Spanish Ministry of Economy and Competitiveness. Danilo Custódio acknowledges the doctoral fellowship SFRH/BD/76283/2011 from the Portuguese Science Foundation. Support is acknowledged to Generalitat de Catalunya 2014 SGR33 and to AXA Research Fund.

Edited by: E. Gerasopoulos

\section{References}

Aiken, A. C., Decarlo, P. F., Kroll, J. H., Worsnop, D. R., Huffman, J. A., Docherty, K. S., Ulbrich, I. M., Mohr, C., Kimmel, J. R., Sueper, D., Sun, Y., Zhang, Q., Trimborn, A., Northway, M., Ziemann, P. J., Canagaratna, M. R., Onasch, T. B., Alfarra, M. R., Prevot, A. S. H., Dommen, J., Duplissy, J., Metzger, A., Baltensperger, U., and Jimenez, J. L.: O/C and OM/OC ratios of primary, secondary, and ambient organic aerosols with high-resolution time-of-flight aerosol mass spectrometry, Environ. Sci. Technol., 42, 4478-4485, 2008.

Alastuey, A., Querol, X., Castillo, S., Escudero, M., Avila, A., Cuevas, E., Torres, C., Romero, P.-M., Exposito, F., García, O., Diaz, J. P., Van Dingenen, R., and Putaud, J. P.: Characterisation of TSP and $\mathrm{PM}_{2.5}$ at Izaña and Sta. Cruz de Tenerife (Canary Islands, Spain) during a Saharan Dust Episode (July 2002), Atmos. Environ., 39, 4715-4728, 2005.

Allan, J. D., Williams, P. I., Morgan, W. T., Martin, C. L., Flynn, M. J., Lee, J., Nemitz, E., Phillips, G. J., Gallagher, M. W., and Coe, H.: Contributions from transport, solid fuel burning and cooking to primary organic aerosols in two UK cities, Atmos. Chem. Phys., 10, 647-668, doi:10.5194/acp-10-647-2010, 2010.

Amato, F., Pandolfi, M., Escrig, A., Querol, X., Alastuey, A., Pey, J., Perez, N., and Hopke, P. K.: Quantifying road dust resuspension in urban environment by Multilinear Engine: A comparison with PMF2, Atmos. Environ., 43, 2770-2780, 2009.

Brunekreef, B. and Forsberg, B.: Epidemiological evidence of effects of coarse airborne particles on health, Eur. Respir. J., 26, 309-318, 2005.

Calzolai, G., Nava, S., Lucarelli, F., Chiari, M., Giannoni, M., Becagli, S., Traversi, R., Marconi, M., Frosini, D., Severi, M., Udisti, R., di Sarra, A., Pace, G., Meloni, D., Bommarito, C., Monteleone, F., Anello, F., and Sferlazzo, D. M.: Characterization of $\mathrm{PM}_{10}$ sources in the central Mediterranean, Atmos. Chem. Phys., 15, 13939-13955, doi:10.5194/acp-1513939-2015, 2015.

Council Directive 2008/50/EC of the European Parliament and of the Council of 21 May 2008 on ambient air quality and cleaner air for Europe OJ L 152, 1-44, 11 June 2008.

Crippa, M., DeCarlo, P. F., Slowik, J. G., Mohr, C., Heringa, M. F., Chirico, R., Poulain, L., Freutel, F., Sciare, J., Cozic, J., Di Marco, C. F., Elsasser, M., Nicolas, J. B., Marchand, N., Abidi, E., Wiedensohler, A., Drewnick, F., Schneider, J., Borrmann, S., Nemitz, E., Zimmermann, R., Jaffrezo, J.-L., Prévôt, A. S. H., and Baltensperger, U.: Wintertime aerosol chemical composition and source apportionment of the organic fraction in the metropolitan area of Paris, Atmos. Chem. Phys., 13, 961-981, doi:10.5194/acp-13-961-2013, 2013.

Draxler, R. R. and Rolph, G. D.: HYSPLIT (HYbrid Single-Particle Lagrangian Integrated Trajectory) Model access via NOAA ARL READY Website: http://www.arl.noaa.gov/ready/hysplit4.html (last access: 6 August 2015), NOAA Air Resources Laboratory, Silver Spring, MD, 2003.

EEA Report No 5/2015 Air quality in Europe - 2015 report, http: //www.eea.europa.eu/publications/air-quality-in-europe-2015 (last access: 3 March 2016), 2015.

Eeftens, M., Beelen, R., De Hoogh, K., Bellander, T., Cesaroni, G., Cirach, M., Declercq, C., Dedele, A., Dons, E., De Nazelle, A., Dimakopoulou, K., Eriksen, K., Falq, G., Fischer, P., Galassi, C., Gražulevičiene, R., Heinrich, J., Hoffmann, B., Jerrett, M., Keidel, D., Korek, M., Lanki, T., Lindley, S., Madsen, C., Mölter, A., Nádor, G., Nieuwenhuijsen, M., Nonnemacher, M., Pedeli, X., Raaschou-Nielsen, O., Patelarou, E., Quass, U., Ranzi, A., Schindler, C., Stempfelet, M., Stephanou, E., Sugiri, D., Tsai, M.-Y., Yli-Tuomi, T., Varró, M. J., Vienneau, D., Klot, S. V., Wolf, K., Brunekreef, B., and Hoek, G.: Development of land use regression models for $\mathrm{PM}_{2.5}, \mathrm{PM}_{2.5}$ absorbance, $\mathrm{PM}_{10}$ and PMcoarse in 20 European study areas; Results of the ESCAPE project, Environ. Sci. Technol., 46, 11195-11205, 2012.

Fine, P. M., Cass, G. R., and Simoneit, B. R. T.: Chemical characterization of fine particle emissions from fireplace combustion of woods grown in the northeastern United States, Environ. Sci. Technol., 35, 2665-2675, 2001.

Gietl, J. K., Lawrence, R., Thorpe, A. J., and Harrison, R. M.: Identification of brake wear particles and derivation of a quantitative tracer for brake dust at a major road, Atmos. Environ., 44, 141$146,2010$.

Gonçalves, C., Alves, C., Evtyugina, M., Mirante, F., Pio, C., Caseiro, A., Schmidl, C., Bauer, H., and Carvalho, F.: Characterisation of $\mathrm{PM}_{10}$ emissions from wood stove combustion of common woods grown in Portugal, Atmos. Environ., 44, 4474-4480, 2010.

Gonçalves, C., Alves, C., and Pio, C.: Inventory of fine particulate organic compound emissions from residential combustion in Portugal, Atmos. Environ., 50, 297-306, 2012.

Hennigan, C. J., Izumi, J., Sullivan, A. P., Weber, R. J., and Nenes, A.: A critical evaluation of proxy methods used to estimate the acidity of atmospheric particles, Atmos. Chem. Phys., 15, 2775 2790, doi:10.5194/acp-15-2775-2015, 2015.

Henry, R. C. and Hidy, G. M.: Multivariate analysis of particulate sulphate and other air quality variables by principal components - Part I: Annual data from Los Angeles and New York, Atmos. Environ., 13, 1581-1596, 1979.

Hoyle, C. R., Boy, M., Donahue, N. M., Fry, J. L., Glasius, M., Guenther, A., Hallar, A. G., Huff Hartz, K., Petters, M. D., Petäjä, T., Rosenoern, T., and Sullivan, A. P.: A review of the anthropogenic influence on biogenic secondary organic aerosol, Atmos. Chem. Phys., 11, 321-343, doi:10.5194/acp-11-321-2011, 2011.

Karanasiou, A., Querol, X., Alastuey, A., Perez, N., Pey, J., Perrino, C., Berti, G., Gandini, M., Poluzzi, V., Ferrari, S., de la Rosa, J., Diaz, J., Pascal, M., Samoli, E., Kelesis, A., Sunyer, J., Alessandrini, E., Stafoggia, M., Forastiere, F., and the Med Particles Study Group: Particulate matter and gaseous pollutants in the Mediterranean Basin: Results from the Med-Particles project, Sci. Total Environ., 488-489, 297-315, 2014. 
Kostenidou, E., Florou, K., Kaltsonoudis, C., Tsiflikiotou, M., Vratolis, S., Eleftheriadis, K., and Pandis, S. N.: Sources and chemical characterization of organic aerosol during the summer in the eastern Mediterranean, Atmos. Chem. Phys., 15, 11355-11371, doi:10.5194/acp-15-11355-2015, 2015.

Kroll, J. H., Ng, N. L., Murphy, S. M., Flagan, R. C., and Seinfeld, J. H.: Secondary organic aerosol formation from isoprene photooxidation, Environ. Sci. Technol., 40, 1869-1877, 2006.

Kukkonen, J., Pohjola, M., Sokhi, R. S., Luhana, L., Kitwiroon, N., Fragkou, L., Rantamäki, M., Berge, E., Ødegaard, V., Slørdal, L. H., Denby, B., and Finardi, S.: Analysis and evaluation of selected local-scale $\mathrm{PM}_{10}$ air pollution episodes in four European cities: Helsinki, London, Milan and Oslo, Atmos. Environ., 39, 2759-2773, 2005.

Lianou, M., Chalbot, M.-C., Kavouras, I. G., Kotronarou, A., Karakatsani, A., Analytis, A., Katsouyanni, K., Puustinen, A., Hameri, K., Vallius, M., Pekkanen, J., Meddings, C., Harrison, R. M., Ayres, J. G., ten Brick, H., Kos, G., Meliefste, K., de Hartog, J., and Hoek, G.: Temporal variations of atmospheric aerosol in four European urban areas, Environ. Sci. Pollut. R., 18, 12021212, 2011..

Lucarelli, F., Calzolai, G., Chiari, M., Giannoni, M., Mochi, D., Nava, S., and Carraresi, L.: The upgraded external-beam PIXE/PIGE set-up at LABEC for very fast measurements on aerosol samples, Nucl. Instrum. Meth. Phys. Res. B, 318, 55-59, 2014

Mason, B.: Principles of Geochemistry, 3rd Edn., Wiley, New York, 329 pp., 1966.

Medina, S., Plasencia, A., Ballester, F., Mücke, H. G., and Schwartz, J.: Apheis: Public health impact of $\mathrm{PM}_{10}$ in 19 European cities, J. Epidemiol. Commun. H., 58, 831-836, 2004.

Meng, X., Wang, C., Cao, D., Wong, C.-M., and Kan, H.: Shortterm effect of ambient air pollution on COPD mortality in four Chinese cities, Atmos. Environ., 77, 149-154, 2013.

Minguillón, M. C., Perron, N., Querol, X., Szidat, S., Fahrni, S. M., Alastuey, A., Jimenez, J. L., Mohr, C., Ortega, A. M., Day, D. A., Lanz, V. A., Wacker, L., Reche, C., Cusack, M., Amato, F., Kiss, G., Hoffer, A., Decesari, S., Moretti, F., Hillamo, R., Teinilä, K., Seco, R., Peñuelas, J., Metzger, A., Schallhart, S., Müller, M., Hansel, A., Burkhart, J. F., Baltensperger, U., and Prévôt, A. S. H.: Fossil versus contemporary sources of fine elemental and organic carbonaceous particulate matter during the DAURE campaign in Northeast Spain, Atmos. Chem. Phys., 11, 12067-12084, doi:10.5194/acp-11-12067-2011, 2011.

Minguillón, M. C., Pérez, N., Marchand, N., Bertrand, A., TemimeRoussel, B., Agrios, K., Szidat, S., van Drooge, B. L., Sylvestre, A., Alastuey, A., Reche, C., Ripoll, A., Marco, E., Grimalt, J. O., and Querol, X.: Secondary organic aerosol origin in an urban environment. Influence of biogenic and fuel combustion precursors, Faraday Discuss., doi:10.1039/C5FD00182J, in press, 2015.

Mohr, C., DeCarlo, P. F., Heringa, M. F., Chirico, R., Slowik, J. G., Richter, R., Reche, C., Alastuey, A., Querol, X., Seco, R., Peñuelas, J., Jiménez, J. L., Crippa, M., Zimmermann, R., Baltensperger, U., and Prévôt, A. S. H.: Identification and quantification of organic aerosol from cooking and other sources in Barcelona using aerosol mass spectrometer data, Atmos. Chem. Phys., 12, 1649-1665, doi:10.5194/acp-12-1649-2012, 2012.

Nava, S., Becagli, S., Calzolai, G., Chiari, M., Lucarelli, F., Prati, P., Traversi, R., Udisti, R., Valli, G., and Vecchi, R.: Saharan dust impact in central Italy: An overview on three years elemental data records, Atmos. Environ., 60, 444-452, 2012.

Nava, S., Lucarelli, F., Amato, F., Becagli, S., Calzolai, G., Chiari, M., Giannoni, M., Traversi, R., and Udisti, R.: Biomass burning contributions estimated by synergistic coupling of daily and hourly aerosol composition records, Sci. Total Environ., 511, 1120, 2014.

Paatero, P.: The multilinear engine - a table-driven least squares program for solving multilinear problems, including the n-way parallel factor analysis model, J. Comput. Graph. Stat., 8, 854888, 1999.

Paatero, P. and Hopke, P. K.: Discarding or downweighting highnoise variables in factor analytic models, Anal. Chim. Acta, 490, 277-289, 2003.

Paatero, P. and Hopke, P. K.: Rotational tools for factor analytic models implemented by using the multilinear engine, Chemometrics, 23, 91-100, 2008.

Paatero, P. and Tapper, U.: Positive matrix factorization: A nonnegative factor model with optimal utilization of error estimates of data values, Environmetrics, 5, 111-126, 1994.

Pio, C. A., Castro, L. M., and Ramos, M. O.: Differentiated determination of organic and elemental carbon in atmospheric aerosol particles by a thermal-optical method, in: Proceedings of the Sixth European Symposium: Physico-Chemical Behaviour of Atmospheric Pollutants, edited by: Angeletti, G. and Restelli, G., Report EUR 15609/2 EN, European Commission, Varese, 706711, 1994.

Pio, C. A., Ramos, M. M., and Duarte, A. C.: Atmospheric aerosol and soiling of external surfaces in an urban environment, Atmos. Environ., 32, 1979-1989, 1998.

Pio, C. A., Cerqueira, M., Harrison, R. M., Nunes, T., Mirante, F., Alves, C., Oliveira, C., Sanchez de la Campa, A., Artiñano, B., and Matos, M.: OC/EC Ratio Observations in Europe: Rethinking the approach for apportionment between primary and secondary organic carbon, Atmos. Environ., 45, 6121-6132, 2011.

Polissar, A. V., Hopke, P. K., Paatero, P., Malm, W. C., and Sisler, J. F.: Atmospheric aerosol over Alaska 2. Elemental composition and sources, J. Geophys. Res.-Atmos., 103, 19045-19057, 1998.

Putaud, J.-P., Van Dingenen, R., Alastuey, A., Bauer, H., Birmili, W., Cyrys, J., Flentje, H., Fuzzi, S., Gehrig, R., Hansson, H. C., Harrison, R. M., Herrmann, H., Hitzenberger, R., Hüglin, C., Jones, A. M., Kasper-Giebl, A., Kiss, G., Kousa, A., Kuhlbusch, T. A. J., Löschau, G., Maenhaut, W., Molnar, A., Moreno, T., Pekkanen, J., Perrino, C., Pitz, M., Puxbaum, H., Querol, X., Rodriguez, S., Salma, I., Schwarz, J., Smolik, J., Schneider, J., Spindler, G., ten Brink, H., Tursic, J., Viana, M., Wiedensohler, A., and Raes, F.: A European aerosol phenomenology - 3: Physical and chemical characteristics of particulate matter from 60 rural, urban, and kerbside sites across Europe, Atmos. Environ., 44, 1308-1320, 2010

Puxbaum, H., Caseiro, A., Sánchez-Ochoa, A., Kasper-Giebl, A., Claeys, M., Gelencsér, A., Legrand, M., Preunkert, S., and Pio, C. A.: Levoglucosan levels at background sites in Europe for assessing the impact of biomass combustion on the European aerosol background, J. Geophys. Res.- Atmos., 112, D23S05, doi:10.1029/2006JD008114, 2007.

Querol, X., Alastuey, A., Rodríguez, S., Plana, F., Mantilla, E., and Ruiz, C. R.: Monitoring of $\mathrm{PM}_{10}$ and $\mathrm{PM}_{2.5}$ around primary par- 
ticulate anthropogenic emission sources, Atmos. Environ., 35, 845-858, 2001.

Querol, X., Alastuey, A., Ruiz, C. R., Artiñano, B., Hansson, H. C., Harrison, R. M., Buringh, E., Ten Brink, H. M., Lutz, M., Bruckmann, P., Straehl, P., and Schneider, J.: Speciation and origin of $\mathrm{PM}_{10}$ and $\mathrm{PM}_{2.5}$ in selected European cities, Atmos. Environ., 38, 6547-6555, 2004.

Querol, X., Pey, J., Pandolfi, M., Alastuey, A., Cusack, M., Moreno, T., Viana, M., Mihalopoulos, N., Kallos, G., and Kleanthous, S.: African dust contributions to mean ambient $\mathrm{PM}_{10}$ levels across the Mediterranean Basin, Atmos. Environ., 43, 4266-4277, 2009.

Querol, X., Alastuey, A., Viana, M., Moreno, T., Reche, C., Minguillón, M. C., Ripoll, A., Pandolfi, M., Amato, F., Karanasiou, A., Pérez, N., Pey, J., Cusack, M., Vázquez, R., Plana, F., Dall'Osto, M., de la Rosa, J., Sánchez de la Campa, A., Fernández-Camacho, R., Rodríguez, S., Pio, C., AladosArboledas, L., Titos, G., Artíñano, B., Salvador, P., García Dos Santos, S., and Fernández Patier, R.: Variability of carbonaceous aerosols in remote, rural, urban and industrial environments in Spain: implications for air quality policy, Atmos. Chem. Phys., 13, 6185-6206, doi:10.5194/acp-13-6185-2013, 2013.

Rahn, K. A.: Silicon and aluminum in atmospheric aerosols: crustair fractionation?, Atmos. Environ., 10, 597-601, 1976.

Romieu, I., Gouveia, N., Cifuentes, L. A., de Leon, A. P., Junger, W., Vera, J., Strappa, V., Hurtado-Díaz, M., MirandaSoberanis, V., Rojas-Bracho, L., Carbajal-Arroyo, L., and Tzintzun-Cervantes, G.: HEI Health Review Committee Multicity study of air pollution and mortality in Latin America (the ESCALA study), Research report (Health Effects Institute), 171, 5-86, 2012.

SEC, 2011.208 final: Secretary-General of the European Commission, Commission Staff Working Paper establishing guidelines for demonstration and subtraction of exceedances attributable to natural sources under the Directive 2008/50/EC on ambient air quality and cleaner air for Europe, Brussels, 15 February 2011.
Simoneit, B. R. T., Schauer, J. J., Nolte, C. G., Oros, D. R., Elias, V. O., Fraser, M. P., Rogge, W. F., and Cass, G. R.: Levoglucosan, a tracer for cellulose in biomass burning and atmospheric particles, Atmos. Environ., 33, 173-182, 1999.

Spencer, M. T., Shields, L. G., Sodeman, D. A., Toner, S. M., and Prather, K. A.: Comparison of oil and fuel particle chemical signatures with particle emissions from heavy and light duty vehicles, Atmos. Environ., 40, 5224-5235, 2006.

Thurston, G. D. and Spengler, J. D.: A quantitative assessment of source contributions to inhalable particulate matter pollution in metropolitan Boston, Atmos. Environ., 19, 9-25, 1985.

Traversi, R., Becagli, S., Calzolai, G., Chiari, M., Giannoni, M., Lucarelli, F., Nava, S., Rugi, F., Severi, M., and Udisti, R.: A comparison between PIXE and ICP-AES measurements of metals in aerosol particulate collected in urban and marine sites in Italy, Nucl. Instrum. Meth. B, 318 130-134, 2014.

Turpin, B. J. and Huntzicker, J. J.: Identification of secondary organic aerosol episodes and quantisation of primary and secondary organic aerosol concentrations during SCAQS, Atmos. Environ., 29, 3527-3544, 1995.

US EPA: Positive Matrix Factorization (PMF) 5.0 Fundamentals and User Guide, http://www.epa.gov, EPA/600/R-14/108, April 2014.

Vidal, E. A., Monfort, E., Celades, I., Querol, X., Amato, F., Minguillón, M. C., and Hopke, P. K.: Application of optimally scaled target factor analysis for assessing source contribution of ambient $\mathrm{PM}_{10}$, J. Air Waste Manage., 59, 1296-1307, 2009.

Watson, J. G., Cooper, J. A., and Huntzicker, J. J.: The effective variance weighting for least squares calculations applied to the mass balance receptor model, Atmos. Environ., 18, 1347-1355, 1984.

WHO: Health effects of black carbon, available at: http://www.euro. who.int/_data/assets/pdf_file/0004/162535/e96541.pdf (last access: 6 August 2015), 2012. 